\section{The practice of "de- genrification" of the Turkish film criticism in the late 1950's: The critical receptions and the aesthetic analysis of melodramas like Three Friends (1958) and Port of the Lonely (1959)}

1950'ler sonu Türk sinema eleştirisinin "türsüzleştirme" uygulaması: $\ddot{U} \mathcal{C}$ Arkadaş (1958) ve Yaln1zlar Rihtim1 (1959) melodramlarının eleştirel alımlamaları ve estetik çözümlemeleri

\author{
Tunç Yıldırım ${ }^{1}$
}

\begin{abstract}
This article focuses on two similar examples of melodramas which are representations of the general aesthetic tendency during the genesis of Yeşilçam period (1948-1959) of the Turkish cinema. This work aims to prove that in the aforementioned era, critical discourse which categorizes, names and classifies movies, imposed the practice of de-genrification for Three Friends and Port of the Lonely. To accomplish this aim, an analysis of comparative critical reception should be done in the first stage. Secondly esthetics analysis for those two movies of the same hybrid genre (melodrama), must be presented.

The hypothesis of the article is that, traditional Turkish cinema historiography which based on the repetition of director centered critical discourse will become outdated, if a new approach that focuses on film genres is approved. Analyzing those two melodramatic and realist movies which are chosen as samples from an historical perspective, and placing them rightly in the tradition of Turkish Cinema, will only be possible with a developed method which cross-reads multiple primary sources and contextualize the critical discourse on the melodrama genre.
\end{abstract}

Özet

$\mathrm{Bu}$ makale, Türk sinemasının Yeşilçam döneminin oluşum aşamasında (1948-1959) genel estetik eğilimi temsil eden tür sinemasi içinde hâkim konumda olan melodram türünün iki benzer örneğine odaklanır. Çalışmanın amacı sinema türlerini isimlendiren, tasnif eden ve ayırt eden dönemin eleştirel söyleminin Üç Arkadaş ve Yalnı‡lar Rıbtımı melodramları söz konusu olduğunda türsü̃lesstirme uygulaması yaptığını kanıtlamaktır. Bunun için ilk aşamada söz konusu filmlerin karşılaştırmalı eleştirel alımlama çözümlemeleri yapılır. İkinci olarak da, aynı melez türe (melodram) giren bu iki filmin estetik çözümlemelerine yer verilir.

Makalenin varsayımı, ancak tür sineması gerçeğini temel alan yeni bir yaklaşımın onaylanması halinde eleştirel söylemi genel hatlarıla tekrar eden yönetmen merkezli geleneksel Türk sinema tarihyazımının aşılacağı yönündedir. Örneklem olarak seçilen bu iki melodramatik gerçekçi filmin tarihsel açıdan açıklanıp Türk sinema geleneği içindeki yerlerine oturtulması ancak çoklu birincil kaynakları kesiştiren ve melodram türü hakkındaki eleştirel söylemi bağlamlaştıran gelişkin bir yöntemle söz konusu olabilir.

\footnotetext{
${ }^{1}$ Yrd. Doç. Dr., Tunceli Üniversitesi, İletişim Fakültesi, RTS Bölümü, tyildirim@,tunceli.edu.tr
} 
Yıldırım, T. (2016). 1950’ler sonu Türk sinema eleştirisinin “türsüzleştirme” uygulaması: Ü̧ Arkadaş (1958) ve Yalnı₹lar Rıbtımı (1959) melodramlarının eleştirel alımlamaları ve estetik çözümlemeleri. Journal of Human Sciences, 13(2), 3181-3203. doi:10.14687/jhs.v13i2.3945

Keywords: Critical Discourse; Critical Anahtar Kelimeler: Eleştirel Söylem; Eleştirel Reception; Melodrama; Model of Genrification; Alımlama; Melodram; Türleştirme Modeli; Practice of De-Genrification; Three Friends; Port Türsüzleştirme Uygulamasi; Ü̧̧̧ Arkadaş; of the Lonely; Memduh Ün; Lütfi Ömer Akad. Y Yalnızlar Rıbtımı; Memduh Ün; Lütfi Ömer

(Extended English abstract is at the end of this document)

\section{GİRIŞ:}

Yakın bir zamanda seri olarak yayımlanan üç ayrıntılı makalemde Türk sinemasının sınırları belirli bir zamansal kesitinin (1948-1959) genel estetik eğilimini o dönemki eleştirel söylemin adlandırarak oluşturduğu beş standart tür (taribî film, komedi, polisiye, melodram ve këy filmi) örnekleri üzerinden tespit edip çözümleyerek, yönetmen merkezli geleneksel Türk sinema tarihyazımı paradigmasından farklılaşan bir bakış açısı sundum (Bkz. Yıldırım, 2015-a: 26-65, 2015-b: 208-244 ve 2015-c: 29-65). Birbirine sıkıca bağlı bu analitik çalışmalarımın nihai amacı, Türk sinema tarihini Yeşilçam merkezli olarak yeniden dönemlendirmek' ${ }^{2}$; filmlerin içeriklerine ve biçimlerine doğrudan etki eden tür sineması etmeninin altını çizmek; yönetmen yaratıcıllğının standart türlerle nasıl etkileşime girdiğini tahlil etmek ve yeni bir Türk sinema tarihyazımı için zorunlu epistemolojik, teorik ve metodolojik altyapıyı hazırlamaktı.

Sorun-tarih odaklı çalışan, kesin bir kavramsal çerçeveden hareket eden, filmsel ve filmsel olmayan birincil kaynaklar üzerine kurulu ampirik çalışmalar yeni sinema tarihi ${ }^{3}$ paradigmasına uygun düşen bir Türk sinema tarihi yazılması için gereklidir çünkü 20. yüzyll Türkiye'sinin kültür ve sanat tarihine damgasını vurmuş sinema fenomeninin bütün karmaşıklığ ancak böyle açıklanabilir. Yalnız arşiv koşulları meselesi ve nitelikli araştırmacı yetersizliği düşünüldügünde böyle bir eserin ancak kolektif bir entelektüel emek ile mümkün olabileceği kolayca anlaşılır. Bilimsel açıdan kabul görecek Türk sinemasının estetik, kültürel, teknolojik, ekonomik ve sosyal tarih(ler)ini ancak bu alanların her birinde ihtisaslaşmış bir üniversiteli uฉman kümesi birlik içinde yazabilir.

Anlaşılacağı gibi, başta Özön (1985, 1995, 1962 [2013]) ve Scognamillo (1998) gibi otodidakt sinema tarihçileri ile Onaran (1994) gibi ilk nesil mektepli sinema tarihçisinin temsil ettiği yönetmen figürünü odak noktasına yerleştiren ve basmakalıp bir tiyatrocu/sinemacı dikotomisi üzerine inşa edilen teleolojik perspektifi aşmak arttk elzemdir. Bu evrimci görüşe göre Türk sinema estetiği teatrallikten sinemasallığa doğru evrilir. Bu kutuplaştırıcı yaklaşım, Muhsin Ertuğrul'un temsil ettiği savunulan tiyatrocuları, Lütfi Akad'ın temsil ettiği ileri sürülen sinemacılarla sürekli çatıştırır. Böylece, erken Yeşilçam dönemi Türk sinemasının estetik karakterini sadece yönetmenlerin sanatsal nitelikleriyle özdeşleştirir ve o yıllara ait eleştirel söylemin önde gelen temsilcilerinin (Attila İlhan, Burhan Arpad, Metin Erksan, Halit Refiğ vs.) günlük gazetelerde çıkan tenkitlerde tescillediği standart türlerin etkisini göz ardı eder (Bkz. Yıldırım, 2015-a: 55-56). Aslında 1950'lerin gündelik

\footnotetext{
2 Önceden önerdiğim ve toplamda beşe bölünen periyodizasyon şekli şöyle: 1. Yeşilşam öncesi istikerarsı ve yetersiz. film yapımı dönemi (başlangıcından (?) 1 Temmuz 1948 tarihli yerli film geçen sinema salonları lehine yapılan korumacı vergi indirimine kadar geçen süre). 2. Yeşillsam sinemasınm oluşumu (1948-1959 döneminde kitlesel film üretiminin sistemleşmesi ve standart türlere dayanan Yeşilçam'ın kendisini kabul ettirmesi). 3. Yeşillsam'in altın çă̆z (1960'da Gecelerin Ötesi’nden yani toplumsal gerçekçi sinema bareketinin ortaya çıkışından 1971'de TRT'nin ulusal çapta yayına başlamasına kadar geçen kısa süre). 4. Yeşilşam'ın ağır krizi (1972'den 1989'a kadar giden bu dönemde seyirci sayısının düşmesiyle talep azalır ve sinema salonlarının hızla kapanması ile de iç pazar daralır). 5. Yeşilçam sonrası dönem ya da ikinci yeni Türk sineması dönemi (yabancı sermaye yasasının 1989'da değiştirilmesi ile Türk sinema endüstrisinin dağıtım ve işletim ağlarının aniden dev Hollywood kurumlarının (WB, UIP) eline geçer ve Yeşilçam sineması birkaç yıl içinde tamamen yok olur. Böylece ortak yapımlar ve bağımsız yapım tarzı öne çıkar).

3 Batı'da akademisyen olan sinema tarihçisi yazarların üniversite ortamında, yeni yöntemler ve her çeşit birincil arşiv kaynakları kullanarak yazdıkları sorun-tarih yaklaşımından hareket eden yeni sinema tarihi modeli Philippe Gauthier'e göre (2011: 95) "son otuz yllın sinema tarihyazımındaki egemen paradigmadır."
} 
Yıldırım, T. (2016). 1950’ler sonu Türk sinema eleştirisinin "türsüzleştirme” uygulaması: Ü̧ Arkadaş (1958) ve Yalnı̊lar Rəhtımı (1959) melodramlarının eleştirel alımlamaları ve estetik çözümlemeleri. Journal of Human Sciences, 13(2), 3181-3203. doi:10.14687/ihs.v13i2.3945

basınında ve çok satan siyasi dergilerinde yayımlanan bu yazıların önemi, sinema sanatçısı olduğu $a$ priori kabul edilen yönetmenin bağımsız hareket edemediğini aksine, yapımcı isteklerine ve tür formüllerine zorunlu biçimde bağlı kaldığını tasdik etmelerinden kaynaklanır. Bu bağlamda, söz konusu dönemin liberal görüşlü gazetesi Vatan'da sinema tenkitleri yapan, tiyatro eleştirisinden gelme Burhan Arpad'ın (1954: 4) melodram konusunda yazdıklarını bir kez daha hatırlamak anlamlı olur:

“[...] Rejisör prodüktörün bükümlerine yüzde yüz boyn eğmeye mecburdur. Her şsyden evvel işadam olan prodüktörlerimiz, için Türk piyasasinda en fąla is yapan filmler de Amerikan ve Misir filmlerinin melodram nevileridir. Böyle olunca da ne kadar emek sarf edilse, rejisör ne kadar idealist olsa, artistlerimiz ne derece kabiliyetli olsa ve hatta ne derece anlayış gösterse, netice yine böyle olacak. Kim bilir daha ne zamana kadar?"(İtalik vurgulamalar benim [TY])

Melodram türünün dönemin Türk sinema endüstrisi içindeki nüfuzunu ve mutlak hâkimiyetini kanıtlayan bu gözlemci görüşü dikkate almamak kusurlu bir tarihçi tavrı olur. Zaten yeni sinema tarihi paradigmasının alâmetifarikası da "sinema tarihinde estetik yaklaşımlar tarafindan marjinalleştirilen popüler tür sinemasını ıslah etmesi ve ona iade-i itibar yapmasıdır." (Chapman vd, 2007: 117)

$\mathrm{Bu}$ makalenin sorunsalı, birbirini izleyen iki yılda, farklı seviyelerde olduğu kabul edilen iki ayrı yönetmen tarafindan çevrilen ama aynı baskın türe giren $\ddot{U}_{c}$ Arkadass ile Yalmı̨lar Rıbtımı filmlerinin nasıl ve niçin bir türsüzleştirme uygulamasına tabii tutulduklarını açıklamaktır.

\section{AMAÇ VE YÖNTEM:}

Bu yazıda, 1950'lerin ulusal gazetelerinde kurumsallaşan sinema eleştirisi üzerinden tespit edip çözümlediğim (Yıldırım, 2015-c: 29-49) ve Yeşilçam'ın başlang1ç evresindeki türsel kimliği temsil eden film nevileri arasında başat konuma sahip melodram türüne ait daha önce ele almadığım iki çetrefil örneğe yer vereceğim. Hemen hemen aynı politik duruşa dâhil sol sinema eleştirmeni çevresinin dikkatini çeken $\ddot{U}_{c}$ Arkadas (Memduh Ün, 1958) ve Yalmı̨lar Rzbtımı (Lütfi Akad, 1959) filmlerinin eleştirel alımlama analizleri ile tür sineması bağlamında yapacağım estetik tahlili karşılaştırmalı bir yöntemle ele alacağım. Böylece adı geçen iki melez melodramı türsü̃leştirerek sadece yönetmen yani auteur yaratıcllğı üzerinden değerlendiren ve Türkiye'ye mahsus geleneksel sinema tarihyazımına doğrudan etki eden dar bakış açısına sahip eleştirel söylemi aşarak Türk sinemasının estetik tarihi için olmazsa olmaz yeni bir çerçeve çizmeyi hedefliyorum. Muhakkak ki, Yeşilçam dönemi Türk sineması dendiğinde (kabaca 1940’ların ikinci yarısından 1980’lerin sonuna kadar giden süreç) genel estetik eğilimin belirleyicisi konumunda olan temel faktör kesinlikle tür sinemasidir.

Peki, türsüzlestirme kavramından ne anllyorum? Öncelikle şunu hatıllatıyorum ki bir türü oluşturma sürecinde tek sorumlu ticaret kurallarına göre işleyen sinema endüstrisi içinde hâkim konumda olan yapımc1 değildir. Eleştirmen grubu hatta seyirciler de herhangi bir türün oluşumunda ve isimlendirilmesinde önemli katkı yapar (Bkz. Altman, 2003: 331). Türün kategorik olarak varllğını bilmek için yapılması gereken basittir. Bir türün tarihini yazmak demek türsel bir adlandırmanın doğuşunu açıklamak demektir (Bkz. Moine, 2008: 119). Sinema eleştirisi kurumunun türlerin tanınmasını sağlayan bu rolü, geçmişteki türleri tarihsel olarak tespit etmek ve tahlil etmek isteyen bugünün sinema tarihçisine çok yardımcı olabilir. Yalnız, uluslararası arenada büyük kabul gören tür sineması uzmanları Amerikalı Rick Altman ve Fransız Raphaëlle Moine'ın unuttuğu şey aynı eleştirel söylemin herhangi bir filmin tür sineması ile ilişkisini örtbas edebileceği ve eseri benim kullanmayı seçtiğim tabirle türsü̈lleştirebileceği yönündedir. Bu rolün karmaşık nedenleri vardır.

Türsüzleştirme uygulamast ismini de alabilecek bu yeni kavramı, herhangi bir filmin türsel kimliğinin bilerek ya da bilmeyerek görmezden gelinmesi ya da kasten unutturulması olarak tanımliyorum. Bu işlemdeki/süreçteki/uygulamadaki baş sorumluluğun da tür sineması örneklerini a priori olarak hakir gören ve ticari bulan seçkinci eleştirmen söylemine ait olduğunu ileri sürüyorum. Yönetmen ile 
Yıldırım, T. (2016). 1950’ler sonu Türk sinema eleştirisinin “türsüzleştirme” uygulaması: Ü̧ Arkadaş (1958) ve Yalnı₹lar Rıbtımı (1959) melodramlarının eleştirel alımlamaları ve estetik çözümlemeleri. Journal of Human Sciences, 13(2), 3181-3203. doi:10.14687/ihs.v13i2.3945

seyirci arasında bir aracı konumunda olan eleştirmen çok beğendiği hatta başyapıt kategorisine çıkardığ1 (yani kanonlaştırdığı) bir sinema filmini ait olduğu tür dışında yalnızca eser sahibi yönetmen övgüsü yaparak alımlayabilir, hatta medyatize edebilir. Böylece eserin estetik karakterinin olmazsa olmaz bir parçası olan türsel etkileri görmezden gelebilir veya filmin ait olduğu türü değersizleştirebilir. Amaç sinema sanatının tek sahibi olduğu kabul edilen yönetmeni öne çıkarıp, ticari sinemanın kötü etkisi olduğu düşünülen pejoratif bir manaya sahip türleri silikleştirmektir. Genelde saf gerçekçilik veya ödünsüz sanat sineması taraftarı olan müşkülpesent eleştirmenlerin ticari sinemanın varlık sebebi olarak gördükleri tekrar/çeşitleme ikiliği üzerine kurulu türlere karş1 tutumları önyargılı ve aşağılayıcıdır. Oysa Moine'ın da belirttiği gibi (2008: 97) "auteur filmi, bir sinemacının kişiliğini ifade etse bile, sıklikla türsel olarak belirlenmiştir." Bu bağlamda özgün bir sanatçı olarak yönetmenin yaptığ1 yenilikçi biçim, biçem ve içerik tercihleri de türlerle etkileşimleri kapsamında değerlendirilmelidir.

Melodram türü örneklerine karşı aynı güvensiz tavır, günümüzün itibarlı gazetelerinin kültür sayfalarında yazan film eleştirmenleri arasında da yaygındır. Uluslararası arenanın en önemli sinema etkinliği Cannes Film Festivali'nin 2015'teki resmi seçkisinde yarışan Çinli yönetmen Jia Zhangke'nin Mountains May Depart adlı filmi bir yandan "melodram türüne yeni bir çeşitleme getirdiği”" ve "melodram diline yenilikçi bir ses getirdiğgi" için takdir edilir ve Altn Palmiye'ye layık görülür, öte yandan bu türün "gerçeğin sinemasiyla flört etmesinden" rahatsızlık duyulur (Bkz. Basutçu, 2015: 18). Eleştirel söylem tarafindan hor görülen melodram türünün en yenilikçi çeşitlemeleri bile sanat sineması seçkinciliğine kurban gitmektedir. Bu bakış açısı, nedense, yüksek sanat içinde melodrama hiçbir yer vermemekte saplantılıdır!

Altman türlerin doğuşunu düşünmeyi önerirken sürekli bir türleştirme (Fr. genrification) sürecinden bahseder (Akt. Moine, 2008: 135). Ona göre, genişleme ve sağlamlaştırma üzerine kurulu bir ikili ilke sonsuz bir süreç olan tür yapımına hükmeder. Altman türleştirme kavramını özellikle Hollywood stüdyo sistemi bağlamında kullanırken, Moine ise türleştirme sürecini Hollywood dışındaki ulusal sinemalara (mesela polisiye türü üzerinden Fransa'ya) uygular (2008: 136-137). Altman'in kullandığ1 türlestirme modeli özünde hangi türün kurumsal hangisinin söylemsel olarak çeşitli süreçler içinde inşa edildiğini açıklamaya yarar (Bkz. Lobato ve Ryan, 2012: 4). Yalnız, seyrettiği filmleri alımlayan ve genel ya da uzman basında arabulucu/araci rolü üstlenen eleştiri kurumu da yazdığı eleştiri metinleri etrafinda bir çeşit türsų̈leştirme işlemi gerçekleştirebilir.

$\mathrm{Bu}$ yazının temel varsayımı türleştirme rolü üstlenen eleştirel söylemin bilinçli bir türsü̈llestirme ujgulaması da yapabileceği yönündedir. Bu görüşümü kanıtlayabilmek için söz konusu yıllarda Türk sinemasına ait melodram türü örneklerinin nasıl bir genel eleştirel alımlama ile karşılaştı̆̆ını cevaplamakla işe başlayacağım çünkü bu mecburi bağlamlaştırma aşamasından sonra örnekleme alınan iki melodram filminin eleştirel alımlama analizlerine ve tür sineması kapsamındaki ayrıntılı estetik incelemelerine geçilebilir.

\section{BULGULAR: 1950’lerde hor görülen melodram türü örneklerinin eleştirel söylem ile imtihan1 ${ }^{5}$ :}

Melodram, sinemaya nereden gelir ve nasıl tanımlanır? Türk sinema eleştirmenleri ve tarihçilerinin bu türe ve türün temsilcilerine bakışları nasıldır? Sinema dışından gelen çok güçlü ve çok biçimli bir tür olarak melodram, aslen tiyatro tarihinin kalıtımıdır. Robert Kolker'in (2009: 293) kapsayıc1 tanımı melodramın geniş sınırlarına dikkat çeker:

"Melodram sinemann keesfinden önce de var olan ve komedi olmayan bütün filmlere hükmeden, kusatic anlatı biçimi, bir temel anlatı ve bir tür olarak anlasslabilir." (İtalik vurgulamalar benim [TY])

\footnotetext{
${ }^{4} \mathrm{Bu}$ filmin Çince adı Shan he gu ren'dir.

${ }^{5} \mathrm{Bu}$ kısmı yazarken daha önceki yazılarımda da kullandığım bazı alıntıları tertipleyeceğim. Bkz. Yıldırım-b 2015: 240; Yildırım-c 2015: 29-33, 37, 43, 51-52.
} 
Yıldırım, T. (2016). 1950’ler sonu Türk sinema eleştirisinin “türsüzleştirme” uygulaması: Ü̧ Arkadaş (1958) ve Yalnı₹lar Rıbtımı (1959) melodramlarının eleştirel alımlamaları ve estetik çözümlemeleri. Journal of Human Sciences, 13(2), 3181-3203. doi:10.14687/ihs.v13i2.3945

Yüksek sanatla popüler sanat arasındaki ideolojik ayrımı meşrulaştıran seçkinci sinema tarihçisi yorumuna göre (Bkz. Özön, 1990: 140-141) “melodram sinemanın en yaygın, gelişmemiş izleyicinin de en çok tuttuğu bir tür ve melodramatik tutum da gerçeğin karikatürleştirilmiş biçimi” olarak kabul edilir. Türk sinema tarihi ile ilgili ilk kitabı 1962'de yayımlanacak sol entelektüel Nijat Özön (1959 [1995]: 139-140) için "melodram anlayışının doğru dürüst bir film gerçekleştirmeye engel olması" ve melodramın sinema sanatı için elzem olan gerçekçilikle uyuşmaması yüzünden bu türe hoşgörüyle yaklaşlamaz.

Yeşilçam dönemi Türk sineması ile melodram türünün neredeyse eşanlamlı ve pejoratif olarak kullanıldığ sol eleştirmen çevreleri, melodram ile realizm terimlerini birbirine kesinlikle karşıt şekilde kullanırlar. Türk sinema eleştirisindeki ezeli melodram düşmanlığından rahatsızlık duyanların başında, 1950’lerdeki “yerli melodramların babası” sayılan Muharrem Gürses’in küçümsenmesini hatalı bulan sinema yazarı Halit Refiğ gelir. Ona göre (1960: 4-5) dönemin yetersiz bulunan bütün filmleri eleştirmenler tarafindan "Gürses melodramlarından farksız" şeklinde kötülenirler. Yalnız bu görüsslerinden sadece dört yıl önce Refĭg film eleştirmenliğine henüz yeni başladığı yıllarda Kemal Film müessesesinin yapımc1-senaryocu-yönetmeni Osman Seden'in Intikam Alevi isimli polisiye filminin suç melodramıyla bütünleşen melez türsel özellikleri onu bir hayli rahatsız etmiştir. Refiğ’in (1956: 24) çok sert tarihsel analizi şöyledir:

"Birkaç yll önce 'Kanun Namına', 'İpsala Cinayeti', 'Katil', 'Öldüren Şehir' gibi filmlerin çıkışı Türk sineması için bazı ümitler vadediyordu. Bu filmler yalnız Amerikan sinemasına mahsus baş döndürücü bir hareketi değil, bazı sosyal yahut psikolojik mevzuları da işlemeye çalışıyordu. Cereyanın neticesi olabilirdi. Ya zamanla mevzular üzerinde durulur, tekniğin gelişmesiyle sağlam eserler yaratma yoluna gidilirdi ya da mevzu büsbütün unutulur, böylelikle sadece harekete dayanan cereyan çürüyüp kaybolurdu. İkinci netice oldu... Mev乏u ile birlikte bareket de kayboldu, vacke vacke melodramlar, verem, gösyaşı ve mezarllk sahneleriyle uyustu kald." (İtalik vurgulamalar benim [TY])

Türler sayesinde egemenliğini meşrulaştıran Yeşilçam'ın işleyişini yıldızsız düşünmek hata olur. Sadık Şendil ve Bülent Oran gibi Yeşilçam sinemasının en üretken senaryocuları Klasik Türk Musikisinin sanat güneşi Zeki Müren'in başrolünü oynadığı şarkilı melodramların (Berdus, Altın Kafes, Gurbet, Kimk Plak) öykülerini yazarlar.

Arpad'ın (1955-a: 5), Müren’in çevirdiği büyük ticari başarı elde eden Son Beste hakkındaki yorumları, Batı sinemasından kopya edilen şarkılı filmlerin Mısır ve yerli melodramların şekline sokulduğunu kanitlamaktadır:

“Zeki Müren'in 'Son Beste'si, Bitmemiș Senfoni', Manakyan Tiyatrosu ve Abdülvebab'in filmleri arasinda karar kilamamışa benæìyor. [...] İstanbul sinema seyircisinin defalarca seyrettiği 'Bitmemiş Senfoni', ihtida etmiş, Romantik musikinin 'Şarkılar Prensi' diye anılan Franz Schubert, Arap filmlerinin şarkıcısı Abdülvehap olmuş. Manakyan tiyatrosu melodram da işe karışstrilmıs ve neticede 'Son Beste' meydana gelmiş." (İtalik vurgulamalar benim [TY])

Abdülvehap ve Manakyan etkileri nasıl açıklanabilir? Bu soruya net bir cevap verebilmek için Türk sinema tarihinde biraz geriye gitmek gereklidir. Muhsin Ertuğrul'un 1931 tarihli ilk sesli filmi İstanbul Sokaklar kendisinden sonra gelecek olan filmlerdeki kötü melodram öğelerini taşımakla itham edilir ve sinema salonlarını savaş sırasında işgal edecek şarkılı Mısır melodramları etkisindeki Allab'ın Cenneti (1939) filmi yanında; Sehvet Kurban (1940) ve Kıskanc (1942) gibi yabanc1 melodramlardan yapılan aktarmalar esefle karşılanır (Bkz. Özön, 2013: 103, 115-117). Hem özgün senaryolardan hem yerli roman uyarlamalarından hem de yeni çevrimlerden hareketle Ertuğrul'un inşa etmeye giriştiği esnek bir tür söz konusudur. Muhsin Ertuğrul sinemasının (melodram olsun ya da olmasın) gerçekçi estetikle olan ikircikli münasebetinin en özgün tahlili hakiki sinema münekkidi Metin Erksan (1953: 4) tarafindan yapılmıştır:

"Fakat 'Mubsin Realizmi’nin en kötü tarafi olaylar bakikatlasttramamasıdvr. Fena bir Manakyan geleneği her an insan rahatsı, etmektedir. Hareketler, mimikler ve konusmalar sabte ve yapmacnktur. Hiçbir motif ve figür yeniden yaratılmamustrr. Mekaniklessmiş ve donmus bir gelenek her şsye bâkimdir. Gülmek mi, ağlamak $\mathrm{m}$ lazım geldiğini bir türlü kestiremezsiniz." (İtalik vurgulamalar benim [TY]) 
Yıldırım, T. (2016). 1950’ler sonu Türk sinema eleştirisinin “türsüzleştirme” uygulaması: Ü̧ Arkadaş (1958) ve Yalnı₹lar Rəhtımı (1959) melodramlarının eleştirel alımlamaları ve estetik çözümlemeleri. Journal of Human Sciences, 13(2), 3181-3203. doi:10.14687/ihs.v13i2.3945

Ertuğrul'un gerçekçiliğini, tarihi mirası ve sürekliliği içinde çözümleyen eleştirmen onun sinemada yaptıklarını Türk tiyatro tarihinin öncülerinden Osmanlı Ermeni'si Mardiros Minakyan'ın (18391920) temsil ettiği teatral gelenekle karşılaştırmaktadır.

Yeşilçam'ın melodramları, Mısır sinemasından gelen aynı türe ait filmlerin güçlü tesiri altında kalır. Yusuf Vehbi, Emine Rızık, Hüseyin Riyazı ve Mısır'ın ses kralı Abdülvehab gibi tanınmış oyuncuların oynadığı Asskın Gözyaşlan, Doğru Yol, Fakir Cocuklar, Allab'm Kudreti, Beyaz Melek, Kaderin Oyuncağı, Günah Cocuğu, Aşk Memnu ve Yıkılan Saadet gibi Türkçeleştirilmiş şark filmleri (hazin, 1stırap, acıklı mesajlar yayarken) aile faciaları ve ibretlik hayat hikâyeleri anlatmaktadır. ${ }^{6}$ Son Beste gibi filmler müzik, popüler edebiyat ve sinemayı aynı türün patetik biçimi içinde harmanlar. Sanat güneşi Zeki Müren'in büyük emek verdiği Berduş'un ise ticari ve türsel olarak neler ifade ettiğini anlamak için genç Refiğ ’in (1957: 32) görüşüne başvurulabilir:

“[...] 'Berduş', mevsimin gişe şampiyonu olmakla kalmamış, kendisinden önceki bütün rekorları da kırrp geçirmişti. Muharrem Gürses okulunun ve bu okulun doğrudan doğruya tesiri altunda kaldiğ̊ Hint melodramlarmnn bir taklidi olan 'Berduss', prodüktör-rejisörü Osman F. Seden'in ticari başarılarının bir başka deliliydi." (İtalik vurgulamalar benim [TY])

1950’lerin melodramları denince akla gelen ilk kişi Muharrem Gürses olmaktadır. Peki, bu yönetmenin eleştirmenler gözündeki imajı nasıldır? Alttür olarak köy filmlerini seri şekilde üreten bir yapımevi politikası (Halk Film) ile bu kategoriye has senaryo, oyunculuk ve yönetmenlikle özdeşleșen bir sinemacı üslubu (Muharrem Gürses) bu dönemde kendilerini kabul ettirir. Gazete tefrikaları sayesinde tanınmış ve çok satan popüler roman uyarlamaları, yabancı filmlerden yapılan melodramatik aktarmalar ve tür dönüştürmeleri vazgeçilmez yapım yöntemlerine dönüşür. Eleştirmenlerin beklenti ufkunda yönetmen Gürses demek teknik bakımdan kötü ve primitif (yani ilkel) demektir (Bkz. Arpad, 1955-b: 5; Kakınç, 1957: 9; Okan, 1957: 2). Bu fenomen yönetmenin siklıkla eleştirilmesinin bir başka sebebi de gerçeklerden ve sinema dilinden uzaklaşmadır. 19551957 arasında çevirdiği üç köy filmi felaket melodramları olarak iz bırakır ama eleştirmenlerin çok büyük tepkilerini alır: Yedi Köyün Zeynebi, Ceylan Emine ve Sazh Damm Kahpesi.

Dönemin eleştirisinin baskın melodram türünün sinemadaki uyarlamalarına karşı da hiç hoşgörüsü yoktur. Semih Tuğrul'un (1954: 4) melodramın has bir örneği hakkındaki tavrı tahammülsüzdür:

"Filmin artist ve teknisyenlerinin canla başla çalısmalarına, iyi niyetlerine rağmen Hıçkımk, konu bakımından pamuk ipliği ile bağlanmış bir entrikaya dayanan, seyircinin ancak merbamet bislerini kışkertmakla ilgi toplayabileceke, içinde kötü melodramm bütün çocukça bileleri bulunan ağır tempolu, çok uzun bir filmdir. 'Hıckernk' filmi Kerime Nadir'in ayn isimdeki romann kurban olmus, romannn kötü ve ucuz melodram unsurlarmin hepsini yüklenmiss." (Italik vurgulamalar benim [TY])

Burhan Arpad (1954: 4) Hıckeırk uyarlaması yorumunda, roman ve film arasındaki yakın melodram bağları yüzünden türe tamamen teslim olmuş yönetmen tenkidi yapar:

"Kerime Nadir'in belki geyrek asir evvel tefrikasi sirasinda okudugum 'Huckerrk' buram buram melodram kokan bir eserdi. Takdim yazilarına nazaran eserin senaryosunu yazan Attf Yllmaz, romanin bünyesinde mevcut bu ağdal melodram unsurlarm, sinema sanatmm ifade icaplarm göz önünde tutarak hafifleteceği yerde, -belki de prodüktörün ticari arzusuna uyarak- ağlamakh ve aconderacak ne kadar sabne dïsïnülebilirse dïsünmiüs ve tatbik etmiş. [...] Artistler, bütün hareket ve ifade imkânlan önceden sık1 sıkıya hudutlanmış melodram havasinn ackklhlŭg içinde seyirciyi ağlatmak ve hıçkrrtmak için çabalamaktan gayri bir şey yapamamaya mahkûm." (İtalik vurgulamalar benim [TY])

Anlaşılacağ1 gibi 1950’lerin filmleri hakkında yazan eleştirmen çevresinin Türk sinemasının melodram çeşitlerine karşı derin bir öfkesi ve muhalefeti vardır. Acaba tür sineması karşıtı olan bu peşin hükümlü ve değersizleştirici eleştirel söylem 1950’lerin sonunda değişecek midir? Dahası, bu tavır ilginç melodram örnekleri ile karşılaştığında nasıl tepki verecektir? Küçümsenen türe meşruiyet mi kazandıracak yoksa o türü ipham mı edecektir?

\footnotetext{
${ }^{6}$ İthal edilen Mısır filmlerinin Türkçeleştirilmiş isimlerine Akşsam gazetesinin 1947-1949 yılları arasında çıkan sayılarından ulaşılmıştır.
} 
Yıldırım, T. (2016). 1950’ler sonu Türk sinema eleştirisinin “türsüzleştirme” uygulaması: Ü̧ Arkadaş (1958) ve Yalnı₹lar Rıbtımı (1959) melodramlarının eleştirel alımlamaları ve estetik çözümlemeleri. Journal of Human Sciences, 13(2), 3181-3203. doi:10.14687/jhs.v13i2.3945

\section{1. $\ddot{U}_{\mathcal{C}}$ Arkadaş’ın eleştirel alımlaması: “Türk sinema tarihinin gelmiş geçmiş en önemli filmi"}

1950’li y1llar Türk sineması deyince eleştirmenlerin, sinemaseverlerin ve geleneksel sinema tarihçilerinin özellikle üzerinde durdukları film, "Memduh Ün'ün umulmayan başarısı" ve o döneme kadar çevrilen "en iyi Türk filmi” gibi etiketlerle abartılı övgüsü yapılan Üc Arkadaş’tır. Başyapıt kategorisine çıkarılan bu sürpriz filmin eleştirel alımlaması ve konusunun esinlendiği Charlie Chaplin filmi Şehir Işıklar (City Lights, 1931) ile yapılan (ama melez türsel etkileşimi göz ardı eden) senaryo karşlaştırması sorunsallaşturılmalıdır. Bu garip eleştirmen tavrına bir de Ü̧ Arkadaşa kadar "Muharrem Gürses usulü ağdalı ve kasvetli melodramları meydana getirenlerden biri (Refiğ 1959-a: 27)" olarak aşağılanan yönetmen Ün'ün yüceltilmesi sorunu eklenmelidir. Aslında, yeni sinema tarihçisinin yapması gereken $\ddot{U}_{c}$ Arkadaş่'n nasıl kasten türlerin (melodram ve komedi) dışına konumlandırıldığını, metinlerarası özelliklerinin göz ardı edildiğini ve iyimser bir gerçekçilik (buna pembe gerçekçilik de denilebilir) kapsamında değerlendirildiğini analiz edebilmektir. Filmlere değer biçme konusunda eleştirmen tavrını bir türlü terk edemeyen sinema tarihçisi Özön'ün şu yorumu (2013: 187) da ancak böyle tarihselleştirilebilir:

"Zira Ün, 1955-58 arasındaki filmleriyle adı en kötü melodramlarla birlikte amulan 'Gürses Okulu'nun başlca temsilcisi sayzlan bir rejisörken, 1958'de Üç. Arkadaş'la en iyi Türk. filmini meydana getirmisti." (İtalik. vurgulamalar benim [TY])

$\ddot{U}$ U̧ Arkadas nasıl oldu da eleştirmenler tarafindan Türk sinema panteonunun kanon filmlerinden biri haline getirildi? Vasat melodramların rejisörü olduğu için hor görülen Ün'ün yönetmenliği nasıl eleştirel söylem tarafindan tescillendi? Bu sorunların çözümü ancak örnek alınan yönetmen-oyuncu Chaplin'in ve popüler filmi Şehir Işılklari'nın hangi türlerle özellikle ilişkilendiril(me)diği sorusu yanıtlanınca çözülebilir. Bu Amerikan filmi çok yakın bir tarihte Türkiye'nin ulusal kanallarından birinde (tv2) televizyon seyircisine gösterildi. Yine sayfalarında hemen hemen her gün sinemaya önemli yer ayıran Birgün isimli ulusal bir sol gazetede çıkan tanıtım yazısı söz konusu Hollywood klasiğini hem komedi türüyle özdeşleştirdi hem de onu "Hüzünlü bir Chaplin filmi" olarak niteledi (2015: 10). Aynı yazı şöyle devam ediyor: "Sonuna kadar kahkahanın eksik olmadığı filmin finalinde, Charlie Chaplin izleyiciyi hüzünlendiriyor."

Demek ki dünya sinema literatüründe romantik komediyle tanımlanan Şehir Işıklar deyince hem komik olan hem de hüzünlü olan akla geliyor. Peki, bu hüzün teması melodram türüyle ilişkilendirilebilir mi? Sessiz sinema döneminin başat türü savruklama ve onun has oyuncu-yapımc1yönetmeni Chaplin düşünülünce bu soruya evet cevabı verilebilir çünkü Şarlo 1920’lerde ve 1930’larda savruklamanın agresif geleneğinden farklılaşan bir melodramatik gelenek tasarlamış ve bunu komik ile patetiği etkili biçimde dokuyarak yapmıştır (Bkz. Pinel, 2009: 42, 138). Bu yazara göre komedinin gidişatında devrimi, Chaplin'in ABD'de çevirdiği bir melodram olan $A$ Woman of Paris (1923) filmi yapmıstır (2009: 54).

Türk eleştirmenler Şehir Işılklarinın $\ddot{U}_{\zeta}$ Arkadas üzerindeki etkisini sadece senaryo kapsamında tespit ettikleri için bu filmi bir kopya ya da taklit olarak değerlendirmemiştir. Hem komediyi hem de melodramı tek bir bünyede birleştiren Chaplin sinemasına özgü melez tür etkisini göz ardı ettikleri için de $\ddot{U}_{\zeta g}$ Arkadaş’ı ve yönetmenini dönemin Türk sinemasının baskın türü melodram nüfuzundan özellikle ayrı tutmuşlardır. Hatta film abartılarak ismi melodramla özdeşleşmiş vasat bir sinemacının bu türden kurtuluşu şeklinde simgeleştirilmiştir. Onlara göre sinema yönetmeni olarak kendisini ispatlayan Ün, türlerin izinde değildir. Ün’ü, Gürses'in tür sinemasindan (yani basmakalıp melodramlardan) tamamen koptuğunu düşündükleri için göklere çıkarırken aynı yönetmeni, Chaplin'in karakteristiği melez tür sineması etkisinden de ayrı değerlendirmişlerdir. Bu bilinçli eleştirel tavrın altında gerçekçi olan ile melodramatik/komik olanı yan yana koymaktan kesinlikle korkan bir eleştirmen şuursuzluğu yatmaktadır. Yani neredeyse oy birliğiyle gelmiş geçmiş en iyi Türk filmi unvanı verdikleri $\ddot{U}_{\zeta}$ Arkadaşı̀n, dönemin eleştirmenleri tarafindan tamamen hakir görülen melodramın türsel etkileriyle ilişkilendirilmesi imkânsızdır. Türsüzleştirme uygulamasının altında rüştünü ispatlayan yönetmen övgüsü yatmaktadır. 
Yıldırım, T. (2016). 1950’ler sonu Türk sinema eleştirisinin “türsüzleştirme” uygulaması: Ü̧ Arkadaş (1958) ve Yalnı₹lar Rıbtımı (1959) melodramlarının eleştirel alımlamaları ve estetik çözümlemeleri. Journal of Human Sciences, 13(2), 3181-3203. doi:10.14687/ihs.v13i2.3945

Peki, bu filmin yönetmeni ne düşünmektedir? Kendi filmlerini yeniden değerlendiren bir kitap yazan Ün'ün görüşleri de filmini itinayla melodram etiketinden uzak tutmaktadır. Sanki bu başat tür, yakalanılmaması gereken ölümcül bir hastalık gibi kabul edilmektedir. Yönetmen, Ü̧̧ Arkadaş'1, "etkileyici bir masal", "gerçekte öyle bir dünyanın var olma olasıllọ̆ yok" diye dürüstçe değerlendirse de filminin en fazla "duygusal bir kurmaca" olduğunu kabul eder (Bkz. Ün vd, 2009: 66). Peki, duygusal kurmaca kategorisiyle ile melodram türü arasında hiçbir ilişki olmadığ1 söylenebilir mi? Söz konusu filmiyle dönemin eleştirmenlerinin beklenti ufkunu beklenmedik şekilde altüst eden Yeşilçam'ın bu ünlü yönetmen-oyuncu-yapımcı figürü (2009: 72) şaşkınlığını gizlememektedir:

"Filmin o kadar başarlı olacağın, bu kadar iyi eleştiri alacağını, o güne kadar yapılan en iyi film seģileceğini, sinema taribimizde bu kadar büyük bir etki yapacă̆gn elbette düşünmemistim." (İtalike vurgulamalar benim [TY])

Türk sinemasında tüm zamanların türlerini tematik sınıflandırmaya sokan Agâh Özgüç de Üg Arkadaş'1 melodramla değil de keyfi biçimde yarattığ1 "illk düzeyli sevgi filmi" ve "popülist sinemanın bir kitle filmi örneği” kategorilerinde isimlendirmeyi uygun görür (Bkz. 2005: 18, 244).

1958 yllı sonunda Beyoğlu semtinin önce Saray sonra Yeni Ar sinemalarında sükseli bir şekilde seyirciyle buluşan $\ddot{U}_{\zeta \zeta}$ Arkadaşs'ın hakkında çıkan yorumlar çok çeşitli ve zengindir. Filmin gazete reklamları da türsel kimliği hakkında bir ipucu vermez. Türlere karşı eleştirel tavrını gerçekçi sinema 1srarı üzerinden her zaman belli eden Refiğ (1959-b: 28) için $\ddot{U}_{\zeta}$ Arkadaş’n soyut başarısı gerçekçi düzlemde değildir:

"Birden, çok umumi mevzulara atlayıveren; günlük meselelerimizi, olaylarımızı, kendimize has yaşayışı teğet geçen, iyilik kavramını mücerretleştirilmiş bir dünya çerçevesinde anlatan 'Ü̧̧ Arkadaş' her halde gerçekçi Türk sinemasmm fikri önderleri arasinda saylmayacaktr. Ama bir prodüksiyon ziłhniyetinin değģsmesine tesir ederse, o zaman rolü büÿ̈̈k olacakttr." (İtalik vurgulamalar benim [TY])

Peki, onun için bu film neden önemlidir? Çünkü Türk sinema ortamıla (Refiğ doğrudan yazmasa bile ben, buna "Yeşilçam" diyorum) ve onun karakteristiğiyle farklı bir ilişkiyi vurgulamaktadır. Bu net bir kopuş, ret veya bağımsızlık olmasa da nitelikli bir çeşitlemedir (1959-b: 28).

“Ǚç Arkadaş'ın yarattı̆̆ iyimserlik duygusuyla, Türk sinemasının öteden beri süregelen bazı münakaşaları yeniden gözden geçirilebilir. Neydi Türk film yapımcilarının öteden beri iddia ettikleri? 1) Eldeki imkânlarla Türkiye'de doğgru dürïst film yapulama\%. 2) İyi film yapulabilse de bunlarn seyircisi olmaそ: 3) Film tenkidçileri, film yapanlarm can dïsmander. 4) Beyoğlu ișletmecileri salonlarmn kapılarm Türk filmlerine açmaz..." (İtalik vurgulamalar benim [TY])

Türk sinema eleştirisinin beklenti ufkundaki yarılmayı en güzel izah eden metin Tuncan Okan'a aittir. U̧̧̧ Arkadaş'ın Türk sinema tarihi içinde nereye yerleştirildiğini ve hangi tür kapsaminda tasnif edildiğini ilk olarak bu eleştirmen tespit eder. Geleneksel sinema tarihçileri de bu yazarın yorumunu açımlayan, yönetmeni efsaneleştiren ve söz konusu filmi Türk sinemasının zirvesine çıkaran görüşler verirler ama türünden özellikle bahsetmezler. Tarihçi Özön'ün yukarıda alıntılanan yorumu dönemin önde gelen eleştirmenlerinden Okan'ın Ü̧ Arkadass alımlaması ile tamamen uyuşmaktadır (1958: 2).

"Yarmm sinema taribçisi, senelerdir uyuya kalan Türk sinemasındaki ferdi kıpırdanmalardan bahsederken Memdub Ün'ün 'Üç Arkadass'na da işaret etmeden geçemeyecektir. Daha önceki kordelalaryla, Türkiye'de ikinci bir Mubarrem Gürses olmaya heveslendiğini hissettiren Memdub Ün'ün 'Üç Arkadaş' gerrçeten bir sürprizdir." (İtalik vurgulamalar benim [TY])

Geleneksel sinema tarihçiliğinin göbek bağını kesemediği film eleştirisinin hem sanat eleştirisinden hem de edebiyat eleştirisinden devraldığı kural koyucu ve değer biģici tavrn reddeden mektepli bir yeni sinema tarihçisi ise Okan'ın şu çok önemli türsel tespitiyle ilgilenir. Eleştirmene göre seyirci, Chaplin'in Şehir Işılklarindan mülhem olan (yani esinlenen) $\ddot{U}_{c}$ Arkadaș' "dramatik komedi" şeklinde sınıflandırabilir. İşte bu melez türsel isimlendirme (yani Yeşilçam'ın özelliği olan türlerin estetik sembiyozu) $\ddot{U} \zeta ̧$ Arkeadaş’'n mizansenini, dekupajını, beşeri yönünü ve gerçekçiliğini başarılı bulan diğer eleştirmenler ve amatör sinema tarihçileri tarafindan tamamen göz ardı edilir. 
Yıldırım, T. (2016). 1950’ler sonu Türk sinema eleştirisinin “türsüzleştirme” uygulaması: Ü̧ Arkadaş (1958) ve Yalnı₹lar Rıbtımı (1959) melodramlarının eleştirel alımlamaları ve estetik çözümlemeleri. Journal of Human Sciences, 13(2), 3181-3203. doi:10.14687/jhs.v13i2.3945

Ali Gevgilili (1958: 2) ise özenle üstünde durduğu ama sosyal ve gerçekçi yanına güvenmediği bu Türk filminin melodramdan kesinlikle ayrıştığını düşünmekte ve onu bir çeşit fantezi olarak kabul etmektedir.

"Melodrama, aşır duyarlĭga çok uygun olan konu, baž diyaloglara rağmen, kendini bundan da dikkeatle siyuryor. " $\ddot{U}_{c}$ Arkadaş' dürüst bir çalışmanın kirlenmemiş ürünü, batılı anlamda bir insanlık fantezisisi olarak kaliyor... Sinema salonundan çıkarken bu izlenimleri birakıyor geride... " (İtalik vurgulamalar benim [TY])

Şair-eleştirmen Salâh Birsel (1958 [2016]: 160), Üg Arkadaş’1 Türk filmciliğinin ilerlediğini haber veren bazı filmler arasına yerleştirir. Bu yorumu da önce senaryo sonra mizansen kanıtları üzerine dayandırır. İyi film yapmanın ilk şartı olarak iyi bir senaryo isteyen eleştirmen için $\ddot{U}_{\zeta}$ Arkeadas senaryo bakımından çok başar1lı bir eserdir. Üstelik senaryonun bütününün gerçekçi bir temele dayanmadığını ve anlatılan hikâyenin yapmacıklığıyla tedirgin olduğunu açıkça yazmasına rağmen, böyle düşünmektedir. Birsel (161) tıpk1 diğer meslektaşları gibi yönetmen övgüsünü onun melodramatik alışkanlığından vazgeçmesine dayandırır: "Memduh Ün, şimdiye kadar Muharrem Gürses janrında birtakım melodramlar çevirirken, birden yeni yola atılmış görünüyor."

Eleştirel görüşlerin çok farklı olduğu bir anda işler ciddileşir çünkü $\ddot{U}_{c}$ Arkadaş’’n yabancı ülkelerde düzenlenen uluslararası film festivallerinde Türkiye'yi rahatça temsil edebileceğini düşünen eleştirmenlerin teşvikiyle yapımcı Talat Emin eserini Cannes Film Festivali’ne gönderme kararı alır (Akis, 1959-a: 30).

Yalnız bürokratik çevreler örtük bir sansürcü tavırla Türk sinemasının uluslararası arenada tanınmasına engel olur çünkü ayaktakımından gelen insanların temsilini yapan $\ddot{U}_{c}$ Arkadas, 1950’lerin siyasi otoritesini rahatsız etmeyi başarır. Basın Yayın ve Turizm Bakanlığı bizzat kendi memurlarından oluşan jüriler kurdurarak $\ddot{U}_{\zeta g}$ Arkadaş'1n "bugünkü Türkiye'yi milletlerarası bir müsabakada temsil edecek durumda olamadığı” yönünde keyfi bir karar alır (Akis, 1959-b: 33). Böylece devlet memurlarının sinema zevki, eleştirmenlerin, seyircilerin ve profesyonel sinema çevresinin estetik beğenisine üstün gelir. Aslında yabancı ülkelerden dikkatle saklanmak istenen fakir insanların Türkiye'si imajıdır.

Resmi makamların bu ilave sansürüne karşı, sinema çevreleri nihayet birlikte hareket eder ve ortak bir bildiri yayınlar. 9 sinema yazarının (Burhan Arpad, Salâh Birsel, Ali Gevgilili, Tarık Dursun Kakınç, Tuncan Okan, Çetin A. Özkırım, Halit Refiğ, Semih Tuğrul, Adnan Ufuk [yani Nijat Özön]), 7 film yönetmeninin (Lütfi Akad, Orhan Arıburnu, Metin Erksan, Şadan Kamil, Osman Seden, Atıf Yılmaz, Baha Gelenbevi), 3 güçlü yapımcının (İhsan İpekçi, Nazif Duru, Hürrem Erman) ve Yerli Film Yapanlar Cemiyeti’nin başkanının (Namık Kılıçoğlu) imzaladığ bu yedi maddelik protesto metni, uluslararası festivallere katılmayı talep eden Türk filmlerinin teknik ve estetik yeterliliklerinin tarafsız sinemacilardan ve film eleştirmenlerinden oluşan uzman bir jüri tarafından ölçülmesi gerektiğini vurgular (Bkz. Gevgilili, 1959-b: 2). Birbirlerinden hoşlanmayan sinema çevreleri (yapımcı loncasıyla eleştirmenler grubu) $\ddot{U}_{\zeta}$ Arkadaş konusundaki demokratik tepkileriyle birleşirler.

Aynı film büyük yankısını Türk Sinema Sanatçıları Derneği’nin isteğiyle Gazeteciler Cemiyeti tarafindan düzenlenen I. Türk Film Festivali'nde yapacak ve jüriyi bölecektir. Böylece Ǘ̧̧ Arkadaş’ın ikinci ve ihtilaflı alımlama süreci başlar çünkü eleştiri çevresinden hemen hemen herkesin üzerinde uzlaştığ1 yllın bu sinema fenomeni festivalden hiçbir ödül alamadan döner. Üstelik 16 jüri üyesinin 10’u film eleştirmenlerinden (Arpad, Birsel, Gevgilili, Kakınç, Refiğ, Özön, Okan, Özkırım, Tuğrul ve Erdem Buri) meydana gelmektedir (Aksam, 1959: 3).

En iyi yönetmen ödülünü köy filmi Ala Geyik’i çeken Atıf Yılmaz, jüri özel ödülünü de eleştirel tarihi film Dokuz Dağm Efesi'nin yönetmeni Metin Erksan kazanır (Vatan, 1959: 5). En iyi film ödülü ise verilemez çünkü oylar bu üç film üzerinde dağllır.

Baykan Sezer daha festivalin başında şu beş filmi (Ala Geyik, Bu Vatanm Cocuklar, Üc Arkadas, Dokuz. Dağın Efesi ve Beraber Ölelim) yapımcıların etkisiyle yarışmaya mecburen iştirak eden büyük melodram grubundan (yani Türk sinemasının genel estetik eğiliminden) ayırmakta ve hangi filmin kazanacağı hatta neden kazanması gerektiği hakkındaki kesin kararını vermektedir (1959: 4). 
Yıldırım, T. (2016). 1950’ler sonu Türk sinema eleştirisinin “türsüzleștirme” uygulaması: Üç Arkadaș (1958) ve Yalmı乏lar Rıbtımı (1959) melodramlarının eleştirel alımlamaları ve estetik çözümlemeleri. Journal of Human Sciences, 13(2), 3181-3203. doi:10.14687/jhs.v13i2.3945

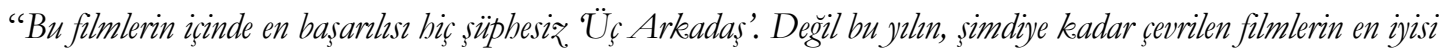
olan 'U̧̧ Arkadaş'm armağanı alması beklenir. Aksi halde daha ilk yllından bu yarışmanın ciddiyetinden şüphelenmek gerekecek." (İtalik vurgulamalar benim [TY])

Aynı gazetede $\ddot{U}$ ç Arkadaş’n savunusunu yapmak işini Erdoğan Tokatlı (1959-a: 3) büyük bir 1srarla sürdürür. O da tiplerin gerçek kaldığı $\ddot{U}_{c}$ Arkadaş’1 en iyi film armağanının tek ciddi adayı olduğunu düşünmektedir. Peki neden? Çünkü sanatçı olarak yönetmen kendi sanatının meşruiyetini ispat etmiştir.

"Memduh Ün, bu filmiyle bugüne kadar sinema dilini kendisinden daha ustalıkla kullanan Lütfi Akad, Osman Seden gibi rejisörlere rağmen Türk sinemasmm en iyi filmini yapts diyebiliriz:" (İtalik. vurgulamalar benim [TY])

Tokatlı (1959-b: 10), hem biçimde hem de içerikte fütursuzca desteklediği bu film hiçbir ödül alamayınca beklenmedik sonucun sebepleri hakkında dönemin en saygın sanat dergilerinden birinde ayrıntılı bir makale yayınlar. Kimi sinema yazarlanının (sadece Tarık Kakınç ismini verir) "aşağıllı", "kötü" ve "ucuz" diye hor gördükleri Üç Arkadaşs', Chaplin'in Şehir Işıklarindan "aşırrllmış" diye eleştirmelerine karşı çıkar. Bundan çıan sonuç, jürinin ister istemez otantiklik ve gerçekçilik ölçütlerini festivalde yarışan filmlerin sanatsal değerlendirmesinde dikkate aldığıdır. Oysa saf bir sinemasever tavırla hareket eden Tokatlı, $\ddot{U}_{\zeta g}$ Arkadaşs1 "şimdiye değin çevrilen en önemli Türk filmi şeklinde" değer biçerek kanonlaşturrr.

$\mathrm{Bu}$ ölçüsüz tenkidçi tavrını, hiç çekinmeden tarihçi Özön de sürdürecektir. Sinema yazarı ve eleştirmeni olarak makaleler veren Özön ile diğer müşkülpesent eleştirmenlerin bu filmi göklere çıkarması ve Türk sinema panteonunun zirvesine yerleştirmesi pek yadırganmamalıdır çünkü bu sol eleştiri çevresi, o güne kadar bu ulusal sinematografinin eserlerini (aslında genel eğilimi olan tür filmlerini) acımasızca tenkit etmekte ve onu hor görmektedir. Sinema sanatını gerçekten temsil ettiğini düşündükleri bir Türk filmi olan $\ddot{U}_{\zeta ̧}$ Arkadaş̧ı savunmalarının ardında bir filmin en sonunda Türk sinemasının sanatsal meşruiyetini ispat ettiğini düşünmeleri yatmaktadır. Bir anlamda kötü ve geri kalmış geçmiş sinemasal geleneği silen ve Türk sinemasının onurunu kurtaran bir yerli film söz konusudur. Buna benzer eleștirmen tavrı 1952'de Kanun Namına alımlamasında ve 1955'de, hem de daha yankılı şekilde, Beyaz Mendilinkinde kendisini göstermişti. Kanonlaştırlmış bu iki filmi, polisiye ve köy filmi türleriyle olan ilişkileri bağlamında çözümlediğim (Yıldırım, 2015-b: 234-239; 2015-c: 57-60) gibi $\ddot{U}_{c}$ Arkadaş¹ da hem tür estetiği (melodram ve komedi) hem de gerçekçi biçim ile karşılaştırmalı bir şekilde abartmadan incelemek gerektiğini düşünüyorum. Gerçekçi estetik ve melodramla karşlaştırmalı çözümleme tavrı hem bu yazının iç tutarlılı̆̆ ve türlere dayalı konusu açısından gerekli hem de yeni sinema tarihi paradigması kapsamında $\mathscr{U}_{c ̧}$ Arkadaş'i tarihsel açıdan açıklamak ve gelenek içine oturtmak zorunluluğundan kaynaklanmaktadır. Bu filmin çeşitli türsel özellikleri harmanlayan senkretik yapısı mutlaka tahlil edilmelidir çünkü Ü̧̧ Arkadaş tamamen melodram ile komedi arasındaki ince bir denge üzerine inşa edilmiştir.

\section{2. $\ddot{U}$ ç Arkadaş'ın estetik çözümlemesi: "Sefil ayak takımına sınıf bilincinin çok dişında kalan 'pembe gerçekçi' bir bakış ya da romantik komediden melodramatik gerçekçiliğe metinlerarası bir geçiş"}

Jenerikte filmin adı görüldükten sonra ilk takdim yazısı meşhur kadın yıldız Muhterem Nur'un ismini gösterir. Boşnak kökenli bu güzel oyuncunun varlı̆̆ doğrudan melodramı (hatta özellikle Gürses’in köy filmi melodramlarını) akla getirir. İşin ilginç tarafı siyah fonda akan jenerikte senaryo kısmının atlanmasıdır. Bu neden kaynaklanır? Sinemada yönetmenlik kariyeri tamamen melodram türüyle özdeşleşmiş Ün'ün Üç Arkadaş’1 çevireceğini öğrenen senarist grubu (Aydın Arakon, Metin Erksan ve Muammer Çubukçu) yazılı eserin sahibi olarak isimlerinin ifşa edilmesini kabul etmezler. Hiçbir iddiası olmayan bu yönetmene karşı önyargilı tutum eleştirmen kesiminden geldiği kadar yönetmen kesiminden de gelmektedir. Meslektaşları kötü bir felaket melodramılla isimlerinin özdeşleştirilmesini kabul etmez. Bu senaryo daha sonra Atıf Yılmaz, Ün ve yönetmen yardımcısı Ertem Göreç tarafindan revize edilerek filme alınır. 
Yıldırım, T. (2016). 1950’ler sonu Türk sinema eleştirisinin “türsüzleștirme” uygulaması: Üç Arkadaș (1958) ve Yalmı乏lar Rəhtımı (1959) melodramlarının eleştirel alımlamaları ve estetik çözümlemeleri. Journal of Human Sciences, 13(2), 3181-3203. doi:10.14687/jhs.v13i2.3945

Anlatının merkezine dört karakter (üçü eril biri dişil olmak üzere) yerleştirilir. Bu anlatı kişilerinin yapılandırılması doğrudan türsel konvansiyonlarla alakalıdır. Ayakkabı boyacısı Mıstık (Semih Sezerli) ve gezgin fotoğrafçı Artin usta (Salih Tozan) komedi türüyle ilişkilendirilir. Zaten sevimli Mıstık’n mızıka çalması, laf ebeliği yapması, argotik üslubu, karşı cinse düşkünlügü ve boyac1 sandığı ile dolaşması dönemin Yeşilçam sinemasına damga vurmaya yeni yeni başlayan komik Cilalı İbo karakteri ile benzeşmektedir. Buna bir de sakarlık motifi çerçevesinde küçük gaglar eklenince komedi etkisi kaçınılmaz olur. Aynı şekilde fotoğrafçı Artin komik bir Ermeni ağzıyla Türkçe konuşmaktadır. İlginç olmasının yanında bu dilsel özellik, dublaj ustası Ferdi Tayfur'un Amerikan komedilerindeki özgün karakterleri çeşitli Türkçe ağızlarında konuşturmasını hatırlatır ve komik etkiyi güçlendirir. Hayali Arşak Palabıyıkyan karakteri ilk akla gelendir. Artin isimli anlatı kişisi de söz komedisi ve sakarlıkla bağlantılı komik etkiler (mesela balık tutarken denize düşme) üzerinden çizilir. Merkezdeki bu iki ana komik karakterin yanında yardımcı komik oyuncular da öne çıkar. Tefeci ve pinti Solomon Efendinin İstanbul Musevi'si vurgusuyla Türkçe konuşmasını, Mevlanakapılı Ayı Recep isimli bir külhanbeyinin sert İstanbul argosuyla konuşması destekler. Böylece ortaya Türk dilinin farklı konuşma üsluplarından faydalanan sözlü bir komik dil çıkar. Bu ayrıca genelinde Türkiye’ye, özelinde İstanbul'a özgü etnik zenginliği (Ermeni, Musevi) gözler önüne serer. Demek ki, Ü̧ Arkadas kendinden önceki sözlü komedi geleneğinden açıça faydalanmakta ve metinlerarası izler taşımaktadır.

$\ddot{U}_{c}$ Arkadaş'ta komik olanın patetik olan ile inceden kaynaşması ve dengelenmesi niyetçi Murat (Fikret Hakan) ile yersiz yurtsuz görme engelli güzel kız (Nur) arasındaki imkânsız aşk temasında kendisini gösterir. Melodram evrenine uygun biçimde bu genç kadın zayıf ve kurtarılmaya muhtaç bir durumdadır. Yani kurban rolü yine kadına biçilmiştir. Doğal olarak onu kurtarması gereken bir eril kahramana ihtiyaç duymaktadır. Duygusallığı güçlendiren aşk teması da kurtarıcı erkek ile kurban kadın arasındaki bilindik melodram ilişkisinin gerçekleşmesine izin verecektir. Masum kadını kurtarmak için fedakârlık yapması gereken onu delicesine seven erkektir. Melodramda doğal olduğu üzere arzunun karşısında muhakkak bir engel çıkar. Bu anlatıda ilk engel melodrama özgü üçlü ilişki değil de gözlerinin görmesi için mutlaka ameliyat olması gereken Gül'ün ihtiyaç duyduğu paradır. Kara sevdanın önündeki ikinci engel ise parayı gasp ederek ameliyatın gerçekleşmesini sağlayan erkeğin hapse düşmesidir. Üçüncü ve son engel de yine melodram türüne özgü biçimde şarkıcı olup zenginleşen ve sınıf atlayan Gül'le sevdiği yoksul erkek Murat arasındaki aşılmaz görünen sınıf farkıdır.

Üç kafadarın yardıma muhtaç bu kızla teması da rastlantı sayesinde gerçekleşir ki bu da melodram anlatısının olmazsa olmaz bir öğesidir. Üç Arkadass'ın doğrusal gelişen anlatımı, melodram anlatısıyla bütünleşen geri dönüşlere yer vermez ve uzun süreli eksiltiler aracıllı̆̆yla ileri doğru gelişir. Geçmişi hakkında bilgi verilen tek anlatı kişisi ise gariban kız Gül olur. Gül'ün korkunç bir kader kurbanı olduğu, alınyazısına isyan ettiğ geçmişte yaşadıklarını anlatmasıyla anlaşılır. Zor geçmişinin bütün ağırlı̆ı̆nı ve trajedisini üstünde taşımaktadır. Dertli, tasalı ve hüzünlü şarkılar söyleyen bu güzel sesli kız, ölen annesini hiç tanımamış, yangında kör olmuş ve babası yeniden evlenince üvey annesinin hışmına uğramıştır. Aile ocağını kaçarak terk eden bu kimsesiz zavallıya ise iyi kalpli melekleri olan üç arkadaş sahip çıkarlar. Hem kendi söylediği melankolik şarkılar hem de dış öyküsel müzik melodrama özgü ekspresif biçimde kullanılır ve bu kadının duygu aşırılığını ifade eder. Murat’ın deneyimlediği ayrılık, aşk acısı ve çaresizlik anlarında da müzik kullanımı aşııdır.

Toplumun kenarındaki küçük insanların yaşadığı maddi ve manevi zorlukları öne çıkaran $\ddot{U}_{\zeta}$ Arkadass sorunları sınıfsal değil de tamamen kaderci temelde ele alır. Gül'ün alt açı, yoğun ışık ve sis kullanımı ile ulvileştirilen bir dua sekansında her şeyi Tanrı'dan beklediği ve ona tevekkül ettiği anlaşılır. Aynı şekilde üç kafadar da "garip kuşun yuvasını Allah'ın yapacağını" düşünmektedir. Dayanışma ve cömertlik ile kodlanan iyilerin karşısında kibir, kendini beğenmişlik ve cimrilikle kodlanan sonradan görme ticaret zengini sınıfın temsilcileri vardır. Çatışma ise sosyo-ekonomik düzlemde değil de hayli göreceli bir felsefi iyi-kötü zıtlı̆̆1 üzerine inşa edilir. Melodram türünün olmazsa olmazı çift kutuplu karakterler (yani körü körüne iyi-kötü şeklinde yapılandırılmış anlatı 
Yıldırım, T. (2016). 1950’ler sonu Türk sinema eleştirisinin “türsüzleştirme” uygulaması: Ü̧ Arkadaş (1958) ve Yalnı₹lar Rəhtımı (1959) melodramlarının eleştirel alımlamaları ve estetik çözümlemeleri. Journal of Human Sciences, 13(2), 3181-3203. doi:10.14687/ihs.v13i2.3945

kişileri) her yerde hazır ve nazırdır. İyiler yoksulları kötüler ise varsılları temsil eder. Diğer melodramlarda olduğu gibi asıl olan aşkıı manevi üstünlüğüdür.

Ameliyat parasını gasp ederek çalan dostları sayesinde gözleri görmeye başlayan Gül, güzel sesi sayesinde meşhur bir şarkıcı olup sınıf atlar. Herkesin hayranı olduğu bu popüler şarkıcı "Dünya geniş bir mezar, sensiz hayatta ne var?" diyerek gamlı türküler okumaya devam etmektedir. Kavuşamadığ1 Murat'a duyduğu aşkın acısını böyle dışa vuran Gül, Yeşilçam’ın burjuva melodramlarında aşk ve ayrılık acısını şarkı söyleyerek çeken (ve seyirciye çektiren) Zeki Müren’in canlandırdığı şarkıcı karakterlerin $\ddot{U}_{\zeta}$ Arkeadaş'taki dişil bir çeşitlemesidir. Ana erkek karakterler nasıl komedi geleneğinden etkilendiyse, başat kadın karakter de Türk sinemasının senkretik melodram geleneğinin bir ürünüdür.

Ana mekân olarak seçilen metruk haldeki Boğaz yalısı bile aslında türün geniş iç mekânlara sahip, şehirli veya taşralı burjuvaların içinde yaşadığı büyük köşklerinin tersyüz edilmiş halidir. Bu gerçek mekânda geçen melodram anlatısı zenginlerin şatafatlı yaşantılarına değil de sefillik içinde temsil edilen küçük insanların günlük yaşamına odaklanır. Aile, evlilik ve baştan çıkarma temalarının çeşitlemelerini işleyen dönemin burjuva melodramlarından kuvvetle ayrilır. Sevdiği âmâ kızı Bebek sırtlarına götürüp ona Boğaz’nn eşsiz manzarasını betimlemek zorunda kalan erkek kahramanın bu tavrı, açık havada park ve bahçe gezintileri yapan melodramın burjuva karakterlerinden pek de farklı değildir. Üc Arkadaş'ın hem Chaplin sinemasından hem de yerli sinemadan etkilenmesi diğer popüler tür filmlerinin alâmetifarikası olan "taklit etme-değiştirme-dönüştürme" yapım şekliyle de tamamen örtüşmektedir.

Film anlatısının mutlu sonla bitmesi de romantik komediyle ilişkili bir konvansiyondur. Son ana kadar birleşmesi engellenen çift nihayet bir araya gelebilir. Yeni yüksek toplumsal statüsünün ve maddi zenginliğinin simgesi pahalı kürk parçasını yere atarak şans eseri sesinden tanıdı̆̆1 arkadaşlarına ve aşkına koşan Gül'ün onlarla birlikte neşeli şarkılar söylemesi dayanışma, fedakârlık ve iyilik temalarının her çeşit maddi engele üstün geldiğini ima etmektedir.

Peki, bu filmin melodramatik gerçekçi özü nerede yatmaktadır? Melodram ile komedinin ortak özelliklerini taşıyan $\ddot{U}_{\zeta}$ Arkadaş่n yüzeysel gerçekçiliği içerikten ziyada biçimdedir. Bu dış gerçekçilik de Ün'ü ve popüler filmini iç gerçekçiliğe dayalı eleştirel filmlerin yönetmeni Chaplin'den farklılaştırmaktadır. İstanbul'un eski mekânlarının (Tophane, Taksim, Gezi Parkı, İstiklal Caddesi, Dolmabahçe sahili, Arnavutköy, Bebek sırtları, Galata Köprüsü vs.) doğal dekor olarak çok başarılı ve yer yer belgesel gerçekçi kullanımına yönetmenin mekânsal bütünselliği ve devamlılı̆̆1 pekiştiren uzun kaydırmalı çekimleri, akıcı dekupajı, eşzamanlı mizanseni ve alan derinliği kullanımı eşlik etmektedir. Ön plan ile arka plana yerleştirilmiş kişilerin arasındaki dramatik ve duygusal farklilığ1 vurgulamada Ün gerçekten başarılıdır. Fransız sinema eleştirmeni André Bazin’in gerçekçi sinema kuramını ve estetiğini 1950'lerin ikinci yarısında Türkçeye makaleler halinde çevirmeye başlayan Özön, Ün'ün üçüncü boyutu yani alan derinliği kullanımını tupkı Bazin gibi gerçekçi estetik kapsamında değerlendirir. Ona göre (1961 [1995]: 93) Ün, Türk sinemasında üçüncü boyuttaki çalışmaların en iyi örneklerini verir. Türkiye'de melodram sinemasının hem biçimde hem de içerikte toplumsal gerçekçi ilk gelişkin ve eleştirel örneği ise Acı Hayat olacaktur.

\subsection{Yalnızlar Rıhtımı'nın eleştirel alımlaması: "Yenilikçi mizansene karşı Türkiye gerçeklerini yansıtamayan senaryo sorunu"}

Sinema eleştirisinin seçkin biçimi üzerinden iltifata boğduğu ama gerçekdışı içeriği sebebiyle yerlere

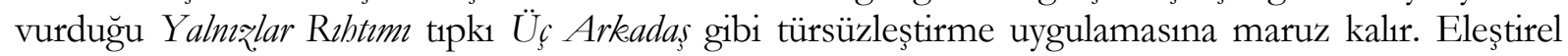
söylem ve onu tekrar eden geleneksel sinema tarihi anlatısı da filmin mizansen yeniliğini överken türü konusunda suskun kalır. Âlim Şerif Onaran'a göre (1994: 59) bu film ancak teknik bir mükemmeliyete ulaşabilmiştir. Özön, filmi biçim-içerik karşıtlı̆̆ı üzerinden kaba bir şekilde yorumlar (2013: 166).

"[Akad] sahne dïrenlemesi, kamera çalsması, bikâye anlatum bakımundan çok ustaca, fakat konu bakımmndan 'garibe' saynlacak Yalmı‡lar Rzbtıminı ortaya koydu." (Italik, vurgulamalar benim [TY]) 
Yıldırım, T. (2016). 1950’ler sonu Türk sinema eleştirisinin “türsüzleştirme” uygulaması: Ü̧ Arkadaş (1958) ve Yalnı₹lar Rəhtımı (1959) melodramlarının eleştirel alımlamaları ve estetik çözümlemeleri. Journal of Human Sciences, 13(2), 3181-3203. doi:10.14687/jhs.v13i2.3945

Mukayese sonucu anlaşlacağı gibi Onaran'ın teknik övgüsü Özön'ün biçimsel çözümlemesi ile yer değiştirmiştir. Yalnız bireyler arasındaki umutsuz bir aşk hikâyesini üçlü/üçgen ilişki çerçevesinde işleyen Yalmılar Rıbtımı neden melodram çerçevesinde incelenmez?

Bir kısım eleştirmen bu filmde Fransız Şairane Gerçekçilik akımının etkisini teşhis etse bile, nedendir bilinmez, bu sinema akımının ait olduğu melodram türünü görmezden gelir. Şairane Gerçekçilik akımına ait filmlerin melodram hatta sosyal melodram olduğu görüşü hâkimdir. $\mathrm{Bu}$ melodramatik damarın Şairane Gerçekçilik sinemasında kara filmin olay örgüsü ile birleştiği düşünülür (Bkz. Journot, 2005: 51). Fransız eleştirisi de bu özelliklere rağmen filmlerin türsel aidiyetini görmezden gelip onları Şairane Gerçekçilik akımı etiketiyle tanımlar. Özgüç (Bkz. 2005: 305-307) işi abartarak Yalnıłlar Rıbtıminı, kendince belirlediği deniz temalı film türünün kaptanlı film kategorisi içine yerleştirir.

Senaryoya konu olan eserde eski sinema eleştirmeni, şair, hikâye ve roman yazarı Attila İlhan'ın payı olan, yönetmenliğini Akad'ın yaptığı, büyük bütçesini de İpekçilere ait FİTAȘ'ın karșıladığı Yalmıəlar Rəłtıminın eleştirel söylemdeki ikircikli yerini (değerli üsluba karşı değersiz tema) mutlaka anlamak gerekir. Vurun Kahpeye, Kanun Namına ve Beyaz Mendil filmleri sayesinde gerçekçilikle anılan ve Türk yönetmenleri içinde büyük saygı duyulan sinemacıya, sanat alanında toplumsal gerçekçilik yanlısı senaryocunun eşlik etmesi eleştiri kurumunun Yalnıəlar Rəhtıminı herhangi bir türle ilişkilendirmesini engellemiştir.

Tuncan Okan'ın olumsuz eleştirisi filmin başarısızlığının asıl sorumlusu olarak senaryocuyu (İhan) gösterir ve senaryoyu edebiyatçllı özentisiyle itham eder (1959: 2). Aynı eleştirmen, oyuncu performanslarını (Çolpan İlhan, Sadri Alışık, Turgut Özatay) da yerin dibine sokar. Özenli fotoğraflarını övse bile başarılı bir sentez yapamayan üslup konusundaki eleştirisi önemlidir çünkü filmin iki farklı tür arasında kaldığını düşünmektedir. Okan farklı türleri terkip etmede başarısız olduğunu düşündüğü Yalnıฆlar Rıbtımı'nı melodram kapsamına ise kesinlikle sokmaz:

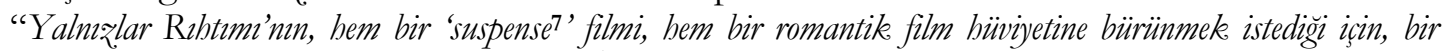
üslup bütünlï̈ü̈ne kavusabilmesi imkânsız:" (Italik vurgulamalar benim [TY])

Gevgilili aynı yllın başında çıkan Akad'ın Zümrüt filmini yerden yere vurarak eleştirir. Vurun Kahpeye, Kanun Namina, Beyaz Mendil ve Meyhanecinin Kıそ̨ (Orhan Kemal’in sinema temalı bir kısa öyküsünden uyarlanma) gibi önemli eserlerin aksine bu yönetmenin, yapımcının senaryo uyarlamasını yaptı̆̆1 melodram unsurları içeren değersiz bir piyasa romanını ekrana taşıdığını düşünmektedir (Bkz. 1959a: 2). Kısacası, memur yönetmenin, yapımcının 1smarlama filmini yapmasından rahatsız bir eleştirmen tavrı vardır. FİTAŞ’ın bu yapımı bünyesinde bir araya gelen Akad, Alışı ve Çolpan İlhan bir sonraki itibarlı projede de yönetmen ve oyuncu olarak birlikte çalışırlar.

Melodramatik Zümrü̈e saldıran Gevgilili'nin tutumu sonraki filmde tamamen değişir çünkü yönetmenin sanatının bu sefer üstün geldiğini düşünmektedir. Gevgilili’nin (Bkz. 1959-c: 4) şekilci tenkidi baştan sona bir yönetmen övgüsüdür, hayranlığıdır hatta savunusudur çünkü ona göre Yalnı̊lar Rəłtımı, "Akad'ın yeniden dirilişidir.” Diyalektik biçimde yaklaşır bu filmin mizansenine ve senaryosuna:

“Açıç̧a şunu demek istiyorum. Lütfi Akad 'Yalmı̨lar Rıbtımi'nn rejisörü olarak mizansen bakımından son ynllar içinde gördï̈ü̈müz en güzel Türk filmini verdi. Ama, filmin konusu filmin mizanseninin iyiliği ölçüsünde kötïydü...” (İtalik vurgulamalar benim [TY])

Filmdeki çevrenin (bar ile rıhtım) ve o çevrenin insanlarının (şarkıcı ve kaptan) Türkiye gerçeğiyle alakası olmadığını düşünen eleştirmene göre Yalnı‡lar Rıbtımı aşk ve kaçakçlık olayı anlatmaktadır. Bu eleştirmen de temanın ikili yapısına değinir.

Salâh Birsel (1959-a [2016]: 229-230), Yalnı̨lar Rəhtımı'nda iyi bir film yapmak isteyen yapımcının samimi çabasını destekler ama Kaptanoğlu'nun Amerikan filmlerini taklitten başka bir gayesi

\footnotetext{
${ }^{7}$ Bu İngilizce terim Okan tarafından "şüphe” manasında tercüme edilir. Asıl karşllı̆̆ "geciktirim” olup özellikle Alfred Hitchcock sinemasıyla özdeşleşmiştir. Aslında klasik sinema estetiğinde yani Hollywood sinemasında yadsınamaz bir yeri vardır. Bu dramatik araç seyircinin sıkıntısını ve bekleyişini yönlendirdiği gibi onun ilgisini canlı tutar.
} 
Yıldırım, T. (2016). 1950’ler sonu Türk sinema eleştirisinin “türsüzleştirme” uygulaması: Ü̧ Arkadaş (1958) ve Yalnı₹lar Rəhtımı (1959) melodramlarının eleştirel alımlamaları ve estetik çözümlemeleri. Journal of Human Sciences, 13(2), 3181-3203. doi:10.14687/ihs.v13i2.3945

olmayan senaryosunun aksaklığı ile zaman zaman yeni-gerçekçi meyiller taşıdığını ispatlayan yönetmenin teatral bir romantizm etkisindeki mizansenine kesinlikle karşı çıkar.

Attila İlhan hem Tuncan Okan'ın hem de Ali Gevgilili'nin senaryo üzerinden kendisini şiddetle eleştirmelerine entelektüel bir tavırla reddiye yazarak cevap verir çünkü tematik içerik üzerinde hiçbir sorumluluk kabul etmez. Tenkidin tenkidini yaptığı iki ayrıntılı yazıda, eseri Ali Kaptanoğlu mahlasıyla FİTAŞ müessesesi için yazdığını ama yönetmen Akad'ın senaryoyu (mekân, tema, karakterler ve diyaloglar başta olmak üzere) tamamen kendi istediği şekilde değisstirerek filme aldığını açıklar (Bkz. 1959-a: 2 ve 1959-b: 4). Söylemek istediği filme alınan senaryonun da tek sahibinin yönetmen olduğudur. Bundan anlaşılan sinema eleştirmenliğinden gelen, sanatta toplumsal gerçekçiliğin $^{8}$ peşindeki yazın adamı İlhan'ın sinema tasavvuruyla Akad'ın film uygulaması arasındaki kopukluktur.' İhan'ın senaryosunu reddettĭgi (ama fena bulmadiğı) bu filme en mühim katkıs1, atmosfer yaratmadaki başarısı ve bunun Fransız sinemasına damgasını vurmuş belirli bir estetik eğilimden etkilenişidir (Akt. Akalın, 2006: 70).

"Beni öteden beri etkileyen Fransız sinemasmm şïrsel gerçekçiligüydi. Oradaki atmosfer benim yazdlklarmda hissediliyordu. O atmosfer orada var. İste o atmosferi Yalmilar Rabtuminda vermeye çalsstum." (İtalik vurgulamalar benim [TY])

Akad'ın edebiyat uyarlamalarında sadık davranmama konusundaki bilinçli tavrı da hatırlanmalıdır. Esinlenmeyi kabullenen ama edebi öyküyü olduğu gibi ekrana taşımaya karşı çıkan özgün bir duruşu vardır (Bkz. Kayalı, 1994: 139). Anılarında yazdığ1 gibi onun için asıl olan yönetmenin görüşüdür. Akad için (2004: 106) yönetim başlı başına özgün bir teliftir yani o, senaryocunun çalışmasından yönetmenin görüşünü bilerek ayırır. Varoluşçu esintiler taşıyan Yalmı̨̧lar Rəbtıminda bugün keşfedilmesi gereken onun tür sinemasıyla girdiği melez ilişkilerdir.

Bu film hakkında en karmaşık çözümlemeyi ve yorumlamayı realist sinema taraftarı Refiğ (1959-c: 11-12) yapar çünkü yaklaşımı sinema tarihine karşılaştırmalı bir bakış açısının ürünüdür. Özünde Yalnı̨lar Rıbtımı kötü ve başarısızdır ama onu etkileyen Fransız Şairane Gerçekçi film Sisler Rıbtımı bir sinema klasiğidir. Peki neden? Çünkü ilki "realiteyi ihmal eden senaryosu", "gerçek olmayan tipleri" ve "anti-sinematografik hikâyesi" yüzünden "çağını yansıtmazken" ikincisi çağının gerçeklerini sembolleştirmektedir. Şair-yönetmen Carné-Prévert ikilisinin Sisler Rıbtımı (Son Buse) ve Gün Doğarken (Son Ümit) filmlerini Fransız kara filmleri içine sokup, kötülerle iyilerin çarpıştı̆̆ çoğu melodramatik konuları gerçek bir trajediye çevirdikleri için alkışlayan Refiğ’in, eleştirdiği Türk yönetmeni savunması tamamen modern biçim (öznel bir kusursuz sinema dili övgüsü) üzerindendir:

"Perdemizde ilk defa olarak sessiz sinemanın 'archaïque' etkilerinden siyrllmıs, tamamen sesli sinema ve modern kamera tekniklerine uygun pür bir sinematografi seyrediyorų:" (İtalik vurgulamalar benim [TY])

Biçimsel yaklaşımında Gevgilili'nin tutumuyla örtüşen Refiğ'e göre Yalmı̨lar Rıbtımi'nın mizanseni her seferinde kötü senaryosuna yenilmektedir. İlginç olan, Refiğ'in, Yalmı̨lar Rıbtımi’nın esinlendiğini düşündüğü Fransız sinema hareketinin türlerle (kara film, melodram) ilişkisine değinmesi ancak aynı ilişkilendirmeyi yorumladığı bu Türk filmi ve melez türler arasında yapmayı uygun görmemesidir. Temanın gerçeklerle uyuşmayışının karşısında büyük bir modern mizansen övgüsü yatmaktadır.

Tüm bu eleştirmen yorumlarından çıkan sonuç 1950’lerin en önemli Türk yönetmeninin Akad olduğudur. Salâh Birsel (1959-b [2016]: 184); Öldüren Şebir, Kaatil, Altı Ölü Var ve Beyaz. Mendil filmlerinin yönetmeni Akad'ın bir müddet için en iyi Türk rejisörü zehabını uyandırdığını yazar. Eleştirmenler bilmeden auteur yani yaratıcı yönetmen övgüsü yapmaktadır çünkü dikkatleri tamamen mizansene yoğunlaşmaktadır. İşte bu nedenle Laurent Tirard'ın (2016: 61) Fransız Yeni Dalga sinema hareketinin öncüsü sinemac1 Jean-Luc Godard'dan aktardığı gibi yönetmen, bir filmin asıl kurucusu ve yaratıcısıdır. Sayıları az olan yaratıcı yönetmenleri eşsiz kılan estetik unsur, bir

\footnotetext{
8 İlhan'ın sanat teorisinde “toplumsal gerçekçiliği” nasıl tanımladığını anlamak için bkz. (1954: 3).

9 Yalmıllar Rəbtımi'nın öykü sahibi İlhan ile senarist-yönetmen Akad arasındaki uyumsuzluğa birincil kaynakları kesiştirmeden bakan, Akad'ın yaptığı değişiklikleri İlhan'ın reddetmesini tamamen göz ardı eden tek taraflı bir auteurist yorum için bkz. (Atam 2014: 139).
} 
Yıldırım, T. (2016). 1950’ler sonu Türk sinema eleştirisinin “türsüzleştirme” uygulaması: Ü̧ Arkadaş (1958) ve Yalnı₹lar Rəhtımı (1959) melodramlarının eleştirel alımlamaları ve estetik çözümlemeleri. Journal of Human Sciences, 13(2), 3181-3203. doi:10.14687/ihs.v13i2.3945

sinemacının benzersiz bakışını ifade eden mizansendir. Yalnı̨̧lar Rıbtımı konusunda mizansen iltifatı yapan eleştirmen alımlaması Akad'ı yüksek bir sinema sanatçısı mevkiine yerleştirir ama aynı eseri üslup ve tema uyuşmazlığı etrafinda sorunsallaşturır. Yönetmenliğini de ispat ettiği için (tıpk1 $\ddot{U}_{\zeta}$ Arkadaş'in sahibi Ün'e yaptıkları gibi) tuhaf filmini melodramla veya başka bir türle iç içe geçirmezler. Eleştirmenlerin zihninde bu iki film Türk sinema estetiğinin üst düzeyini temsil ettiğinden Yeşilçam'a özgü basit tür sinemasıyla karıştırılmamalıdır. Akad'ın kendisi de filminin biçimsel etkisinden övgüyle bahsetmektedir. O, "derinliğe mizansen” kullanımı sayesinde Yalmı̨lar Rıbtıminın bir "kilometre taşı" olduğunu düşünmektedir (Bkz. Onaran, 1990: 90-91).

İsimsiz çıkan bir film eleştirisi Yalnı̨̧ar Rəbtımı'nın yalnızlık, karaborsacılık, aşk temalarını işlemeye çalıştığını ama liman ve denizcilik hayatını kesinlikle veremediğini belirtir (Bkz. Akis, 1959-c: 31-32). Başarı temada değil ama yine biçimdedir. Yönetmenin maharetinin atmosfer yaratmada ve bunu filmin başından sonuna kadar istikrarla sürdürmede yattı̆̆ını düşünen meçhul yazar, Yalnıฆlar Rəbtıminı yukarıda adı geçen Fransız sinema akımıyla değil de belirgin bir başkarakter üzerinden Hollywood sinemasına özgü meşhur gangster filmleri türüyle ilişkilendirir:

"Yalmılar Rıbtımi’nda Amerikan filmlerini hatrlatan yalmı bir kişi var. Verdiği emirler, takındığı tavırlar ve giydiği elbiselerle çete reisinin gangster filmlerinden aktarldiğgna ș̈̈phe yok." (İtalik vurgulamalar benim [TY])

\subsection{Yalnılar Rıhtıminın estetik çözümlemesi: “Melankolinin İstanbul'daki yalnız atmosferi ya da gangster filminin varoluşçu melodramla füzyonu"}

Yalnı̊lar Rəbtıminın sinematografik çözümlemesinde yeni sinema tarihçisinin karşılaştuğı en az üç problem var:

1/ Filmin biçemsel ve biçimsel karakterinin gerçekten Şairane Gerçekçi akımın estetiğiyle uyuşup uyuşmadığını bulmak. Özellikle görsel atmosfer karşılaştırması yaparken eserin metinlerarası karakteristiğini keşfetmek.

2/ Filmin, melodram türü ve gangster filmleriyle nasıl bir melez etkileşime girdiğini tespit etmek. Bunu yaparken ise eleştirmenlerin ve eleştirel söylemi genel hatlarıla tekrar eden geleneksel sinema tarihyazımının yapmadığını yapmak. Yani, Tabir ile Zübre ve Kanun Namına gibi önceki Akad filmleriyle Yalnılar Rıbtımı arasında ortak özellikleri belirlemek amaciyla metinlerarası karşılaştırma yapmak. Buna Akad sinemasının karakteristiği olan "döngüsellik analizi" eklenmelidir.

3/ Fransız sinema dergisi Cabiers du cinéma'yı takip eden, olas1lıkla André Bazin'in hayranı olduğu kimi gerçekçi yönetmenlerin (Jean Renoir, Orson Welles, William Wyler, Roberto Rossellini vs.) ince üslup tahlillerini yaptğ̆ meşhur yazılarını okumuş, Frenk kültürüne aşina entelektüel yönetmenin gerçekçi üslup konusundaki esinlenmesinin Şairane Gerçekçi geleneğin dışından gelip gelemeyeceğini tespit etmek. Yani, Yalmılar Rəbtıminın alâmetifarikası alan derinlikli dekupaj, uzun çekimler (hatta plan-sekans) ve eşzamanlı mizansen tercihlerinin asıl estetik kökenini ifşa etmek. Bu da dünya sinema tarihi bünyesinde yapılması gereken gerçek manada bir formel bağlamlaştırma, tarihselleştirme ve yerleştirme çabası gerektirir.

Yalnıłlar Rıbtımı her şeyden önce kendilik bilinci olan ve kendini yansıtmaktan çekinmeyen bazı özellikler taşır. Film, jenerikle birlikte başladığında bu iki modern estetik karakter kendini derhal belli eder. Limanda gösterilen büyük kasalardan birinin üzerinde "Rejisör: Lütfi Ö. Akad İstanbul" yazmaktadır. Eser sahibi (auteur), ismi üzerinden kendisini bilerek ve isteyerek filmsel kurmaca evrenin bir parçası haline getirir. Bu bilinçli tavır seyirciye, "bir film izliyorsunuz ve bunun tek yaratıcısı benim" demektedir. Tek bir uzun çekimden ve yatay çevrinmeden meydana gelen bu yavaş ritimli giriş iki dakikadan fazla sürer. Koyu bir gri tonun hâkim olduğu bu planda dişşöyküsel müzik bir anda kesilir ve (dişil) diş sesin derinden okuduğu şiirin şu dizesi filmin kendini yansıtan özelliğini ifşa eder: "Nereye baksan ölüm gibi susar Yalnızlar Rıhtımı." 
Yıldırım, T. (2016). 1950’ler sonu Türk sinema eleştirisinin “türsüzleștirme” uygulaması: Ụ̈ Arkadaș (1958) ve Yalmı乏lar Rəhtımı (1959) melodramlarının eleştirel alımlamaları ve estetik çözümlemeleri. Journal of Human Sciences, 13(2), 3181-3203. doi:10.14687/ihs.v13i2.3945

Filmin ana karakteri Kontes Güner (İlhan) bu şïri okumasının yanında ayna yerine itinayla konmuş kameraya bakarak konuşur. Aslında izleyiciye hitap etmenin ince bir biçimi olan bu teknik seçim kendilik bilincini vurgular. Dönemin melodramlarında seyirciye bakarak ağlama, isyan etme, sitem etme veya dua etme patetik bir üslup tercihidir. Akad bunun daha kaba biçimini ilk melodramlarından biri olan Tahir ile Zübre'de kullanmıştı. Bar kadınının bizzat söylediği melankolik şarkılar (mesela, "Senin için ağlar, şu öksüz kalbi dinle”) aşırı duygusal durumunu anlatmaktadır. Bu abartılı müzik kullanımı, Zeki Müren'in oynadığı dönemin şarkılı melodramları akla getirir. O yılların yerli melodramları şarkıcı karakterler bakımından hep zengindir.

Yalmı̨lar Rıbtımı tıpkı şairane gerçekçilik akımı gibi çok hatta özenle yazılmış uzun diyaloglardan meydana gelmektedir. ${ }^{10}$ Kendine has edebi ve şiirsel dil özellikleri taşır. Akad bir anlamda şair İlhan üslubunu sinemalaştırma işine girişir. Dekora verilen önem konusunda ortak yanlar olduğu gibi farklılaşan ciddi özellikler de vardır. Bu Fransız sinema akımına giren filmlerin en önemlilerinin dekorları stüdyoda Alexandre Trauner tarafindan inşa edilir ve bu yapay dekorlar, işçi çevresinin ve banliyölerin fakir mekânlarını sinemaya taşır. Oysa Yalnıそlar Rıbtımı anlatısını ağırlıklı olarak doğal yani gerçek mekânlara (liman) yerleştirir ve bu şehir ortamının apaçık bir sınıfsal özelliği yoktur. Şairane gerçekçilik filmleri merkezcil (Fr. centripète) imajlar yaratırken Yalnıə̧lar Rıbtıminnda Akad dış alana ayrı bir önem verir. Dış alanda yaşananlar en az iç alanda görünenler kadar önemlidir. Akad kamerasını bilinçli bir üslup tercihi olarak tamamen sabitler ve neredeyse hiç kımıldatmaz. Oysa şairane gerçekçilik bağlamında kamera hareketleri önemlidir. Özellikle Marcel Carnénin klasik dekupajını, motive edilmiş kamera hareketleri destekler ve tamamlar. Sisler Rıbtımı buna güzel bir örnektir.

Her iki taraf estetize edici bir siyah-beyaz aydınlatmasından kötümser bir atmosfer yaratmada itinayla faydalanır. Kesme taştan döşenmiş, ters 1 şıkla aydınlatılmış, yağmurla yıkanmış Arnavut kaldırımlı yolları iki kesim de özenle kullanır. Gri renkli bir atmosfer de siyah-beyaz kontrastına dayalı görsel estetiği yer yer destekler. Sisli ve grenli imajlar isteyen ve yaratan Carnénin renk tercihi ağıllıklı olarak gri tondan yanadır. Akad için ışık-gölge oyunları, siluetler, abajurlu lambalar, buzlu camlar, duvar lambaları, gaz lambaları ve jaluziden sızan ışı̆̆ın gölgeli çizgileri iç mekânların olmazsa olmazlarıdır. Tekinsiz ortamları dramatize eden 1şık kaynakları özellikle belirginleştirilir.

Yazg1, kadercilik, duygusal tecrit, aşk arayışı hem Yalmı‡lar Rıbtımı'nda hem de şairane gerçekçilikte esas meselelerdir. İki tarafin tamamen örtüştüğ̈ estetik tercih ise türlerin karışturılması yani melezleştirilmesidir. Sembiyotik bir akım olan şairane gerçekçilik, melodram ve kara filmin özelliklerini bağdaşturır. Yalnılar Rəbtımı ise kurtarılmayı bekleyen, kurban, düşmüş, alkolik, melankolik ve zayıf kadın şarkıcı karakter üzerinden melodrama sırtını dayarken, gangster filmlerine de kaçakçılık teması ve çete öğesi üzerinden göz kırpar. Kuşatılmışlık hissi veren ve karakterleri hapseden çerçeve içinde çerçeve kullanımı da Akad'ın melez bir polisiye örneği Kanun Namına'dan beri başvurduğu biçimsel tercihdir. Yönetmen önceki filmlerinde kullandığı bu tarz stilistik unsurları Yalmı̨lar Rıbtıminda daha rafine bir şekle sokar.

Uzun deniz yolculuklarından dönme kaptanlardan, çete üyelerinden ve bar kadınlarından meydana gelen karakterler dönemin Türkiye'sinin toplumsal ortamı için hayli marjinaldir. Yalmı̨̧lar Rıbtıminda herkes öyle ya da böyle bir varoluş sorunu olan yalnızlıkla mücadele etmektedir. Aşkın hüznü ve melankolisi de bu tematiğin parçası olur. Kontes Güner'i canlandıran İlhan'ın patetik oyunculuğu melodram temsiline uygun düşer. Anlatının merkezindeki bu masum kadın varoluşsal bir kriz içinde kıvranmakta, kaderin ve kendisine sadikçe tutkun çete reisi Ali'nin (Özatay) şiddet kurbanı konumundadır. Onu arzulayan ve onun arzuladığı Rıdvan kaptan (Alısılk) arasındaki tek engel olan eril karakter "Amerikan Ali", gangster filmlerinden firlamış gibi zalimce hareket etmektedir. Bu anlatı kişisinin varlığı da metinlerarası bir göndermedir. Melodramın imkânsız aşk temasını gangster filmlerinden türeme kaçakçılık teması dengeler. Dolar kaçakçıllı̆ı suçu o yılların Türkiye'sinin gerçek sorunlarındandır. Yalmı̨lar Rıbtımı'nda denge tabii ki kıskançlık engeline takılan aşktan yanadır.

\footnotetext{
${ }^{10}$ Bu Fransız sinema akımının derlenen estetik özellikleri için bkz. (Journot 2005: 50-51).
} 
Yıldırım, T. (2016). 1950’ler sonu Türk sinema eleştirisinin “türsüzleştirme” uygulaması: Ü̧ Arkadaş (1958) ve Yalnı₹lar Rəhtımı (1959) melodramlarının eleştirel alımlamaları ve estetik çözümlemeleri. Journal of Human Sciences, 13(2), 3181-3203. doi:10.14687/ihs.v13i2.3945

Klasik olay örgüsü çift nedensel yapı üzerine inşa edilir. Bir taraftan çetenin kaçakçllk işleri diğer taraftan ise reis, kontes ve kaptan arasındaki üçlü/üçgen aşk ilişkisi çıkmazı işlenir.

Bu melez filmin baştan sona melodrama özgü her şeyi bilen anlatımdan meydana geldiği tam olarak söylenemez. Kara filme özgü kısıtlanmış anlatım kullanımı seyircinin merak duygusunu arttırmaktadır. Çetenin içine sızmış bir polis muhbirinin ve çetenin içindeki açgözlü hainin varlı̆̆ da son ana kadar ima edilir. Bunlar ve paralel kurgu kullanımı doğal olarak geciktirim hissini arttırır ve polis botunun müdahalesine kadar seyircinin ilgisini canlı tutar. Film anlatısının kesin bir sonuca varmadan modern sinemaya özgü "açık son" ima etmesi, anlatının başındaki modern estetik özellikler olan "kendilik bilinci" ve "kendini yansıtma" ile uyuşmaktadır. Çete reisini yumruklarıyla ekarte eden ve kurban kadını kurtaran eril karakter, yağmurdan sırılsıklam olmuş, ters 1şıkla loş olarak aydınlatılmış Arnavut kaldırımlı bir sokakta müphem bir geleceğe doğru sevgilisiyle yürürken vince yerleştirilmiş sabit kamera dikey olarak ağır ağır yükselmektedir. Yönetmenin bu yorumu, söz konusu çiftin geleceğinin belirsizliğini anlamlandırarak olası bir mutlu sona karşı gelmektedir.

Yalmı̨lar Rəbtıminı dönemin Türk filmlerinden farklılaştıran en önemli özellik, sahip olduğu melez dekupaj ve Batı sinematografilerine yerleşmiş gerçekçi sinema estetiğinin biçimsel öğeleriyle (zamansal ve mekânsal bütünlügü koruyan uzun süreli çekimler, yer yer kullanılan plan-sekanslar ve alan derinliğine dayalı karmaşı mizansen) yakın ilişkisidir. Bir sene önce çevrilen $\ddot{U}_{c}$ Arkeadas filminde de yer yer rastlanan bu gerçekçi öğeler Akad'ın melodramında en yüksek seviyede kullanılır. Şurası kesindir: Akad'ın biçimsel ve biçemsel tercihleri Carné'nin baştemsilcisi olduğu şairane gerçekçiliği aşmaktadır ve ondan farklılaşmaktadır. Bu sebepten Yalmılar Rıbtıminda basit bir klasik dekupaj çalışması söz konusu değildir. Sisler Rəətıminnda bulanık (flu) görüntüler genellikle arka plan(lar)1 işgal eder. Kısmi bir alan derinliği tercihi ön planda konuşan karakterleri merkeze yerleştirir ve izleyicinin dikkatini söz söyleyenlere yoğunlaşturır. Kompozisyonun ana odağında konuşan insan(lar) vardır. Aç1-karşı açı bu dramaturjinin yaygın bir teknik unsuru olur ve montaj1 akıcılaştıran çekimlerin süresi Yalnı‡lar Rəbtıminkilere göre daha kısadır. Ön plan, orta plan ve arka plana yerleştirilmiş oyuncuların eşzamanlı mizanseni ile üçüncü boyutu yani derinliği vurgulayan çekim teknikleri kullanımı Akad', Fransız Renoir ve Amerikan Welles'in estetik uygulamaları kapsamına çeker. Akad içerikte olmasa da, biçim ve biçemde 1940’lar sinemasının gerçekçi estetiğinin peşindedir. Seyircinin gözü kompozisyonun her yerinde olmalıdır çünkü ortada karmaşık bir mizansen vardir.

\section{SONUÇ:}

$\mathrm{Bu}$ çalışmayı düzenlerken sorduğum ve cevabını aradığım temel soru sinemada türlerin belirlenmesinde ve tanınmasında önemli bir görev üstlenen eleştirel söylemin türsüzleștirme uygulaması yapıp yapamayacağıydı. Yani günümüz sinemabilimi araştırmalarında çok önemli bir yer kaplayan tür incelemelerinde, türleștirme rolü olduğu kabul edilen sinema eleştirisinin çeşitli keyfi nedenler (popüler sinemanın alâmetifarikası olduğu bilinen tür karşıtlı̆̆1, mutlak realizm taraftarllğı, salt sanat sineması tutkusu, yüksek sanat elitizmi, aşırı bir yaratıcı yönetmen övgüsü, ideolojik bakış açıları vs.) yüzünden türsü̈leşstirme işlevi görmesinin ispat edilmesiydi. Bir kavram olarak türsü̈leşstirme uygulamasına ampirik meşruiyetini kazandırabilmek için örnek olay çalışması yapmak elzemdi.

1950’lerin Türk sinema eleştirisi söz konusu olduğunda kesinlikle istenmeyen ve küçümsenen, ayrıca sinema düşmanı bir tür olarak kabul edilen melodram örnekleri ve temsilcileri bu problematiğin çözümü için vazgeçilmez bir altküme olarak kullanılabilirdi. Nitekim farklı sinema eleştirmeni söylemleri karşılaştırıldığında, bu çevrede erken dönem Yeşilçam sinemasının popüler melodram nevilerine karşı gösterilen ortak reddiyeci tavır aşikârdır. İşte yapılması gereken bu dönemde tu kaka ilan edilen adı geçen türe ait olduğu estetik çözümlemelerle kanıtlanacak ama aynı zamanda eleştirmen çevresinin türsel kimliğini yok saydığ1 film(ler) bulabilmekti.

1958 tarihli $\ddot{U} c$ Arkadas ve 1959 tarihli Yalmı̨lar Rıbtımı filmlerinin karşılaştırmalı ikili okuması; koşulsuzca yapılan sanatçı yönetmen, modern mizansen veya en iyi Türk filmi övgüleri üzerinden 

Rıbtımı (1959) melodramlarının eleştirel alımlamaları ve estetik çözümlemeleri. Journal of Human Sciences, 13(2), 3181-3203. doi:10.14687/ihs.v13i2.3945

eleştirel söylemin karmaşık estetik özelliklerden meydana gelen bu melez melodramları tamamen türsüzleştirdiğini ispat etmiştir. Sanatçlların yönetmen kimlikleri hemen tanınırken eserlerin türsel kimlikleri gözardı edilmiştir. Melodram türüne bir türlü güvenemeyen bu inkâr edici eleştirmen söylemi neredeyse olduğu gibi geleneksel Türk sinema tarihyazımında devam ettirilmiş ve Türk sinemasına ait bazı filmlerin türsel kimliklerinin estetik çözümlemelerini geciktirmiştir. Artık yapılması gereken Türk sinemasının estetik tarihi yazılırken yönetmen merkezli dar bakış açısının sınırlarını aşmak ve filmlerin içeriklerine olduğu kadar yönetmenlerin üsluplarına etki eden tür sineması gerçeğini kabullenmektir.

\section{KAYNAKÇA:}

Akad, L. (2004). Işılkla Karanlık Arasında. İstanbul: Türkiye İş Bankası Kültür Yayınları.

Akalın, N. (2006). Şehir Filmleri Attila İlhan. İstanbul: + 1 Kitap.

Altman, R. (2003). "Sinema ve Tür". Dünya Sinema Taribi. Geoffrey Nowell-Smith (Ed.). Çev. Ahmet Fethi. İstanbul: Kabalc1: 322-333.

Anonim (1959-a). “Cannes'a Doğru”. Akis 251: 30.

— (1959-b). "Kaçırılan Firsat". Akis 252: 33.

— (1959-c). "Yalnızlar Rihtımı". Akis 277: 31-32.

_ (30 Mayıs 1959). “Türk Film Festivali Sonuçları". Vatan: 1, 5.

_ (31 Mayıs 1959). “Türk Film Festivali”. Akşam: 3.

_ (28 Haziran 2015). "Hüzünlü Bir Chaplin Filmi”. Birgün: 10.

Arpad, B. (15 Şubat 1954). "Hiçkırık". Vatan: 4.

_ (6 Mart 1955-a). "7 Büyük Sinemada Yeni Türk Filmleri Oynuyor”. Vatan: 5.

_ (17 Nisan 1955-b). “Yedi Köyün Zeynebi”. Vatan: 5.

Atam, Z. (2014). “Auteur Kuramı ve Türkiye Sineması'nda Yaratıc1 Yönetmenler...”. Sinemada Bir Asır: Türk Sinemasinın 100. Yılına Armağan. Ş. Abdurrahman Çelik (Ed.). Ankara: ANSET: 131-143.

Basutçu, M. (22 Mayıs 2015). "Çin Uyandığında". Cumburiyet. 18.

Birsel, S. (29 Aralık 1958 [2016]). “Üç Arkadaş”. Yeni Sabab: 160-162.

_ (22 Şubat 1959-a [2016]). “Zümrüt”. Yeni Sabab: 184-186.

_ (31 Ekim 1959-b [2016]). "Yalnızlar Rihtımı". Yeni Sabab: 228-230.

_ (2016). Beyoğlu’nda Büyülü Geceler 1950’lerde Sinema. İstanbul: Agora.

Chapman, J. vd. (2007). The New Film History: Sources, Methods, Approaches. Palgrave Macmillan.

Erksan, M. (15 Ekim 1953). "Gizli Yara”. Dünya: 4.

Gauthier, P. (2011). "L'histoire amateur et l'histoire universitaire : paradigmes de l'historiographie du cinéma". Cinémas 2-3: 87-105.

Gevgilili, A. (20 Aralık 1958). "Ümit Veren Film”. Vatan: 2.

_ (22 Şubat 1959-a). "Zümrüt”. Vatan: 2.

_ (16 May1s 1959-b). "Festivallere Giden Yol". Vatan: 2.

_ (31 Ekim 1959-c). "Lütfi Akad Artık Olgunluk Çağında". Vatan: 2.

İlhan, A. (1954). "Sosyal Realizm Ne Olmak İstiyor?". Yeditepe 74: 3.

_ (6 Kasım 1959-a). "Yalnızlar Rıhtımı Dolayısıyla Attila İlhan'ın Açıklaması". Milliyet. 2.

_ (9 Kasım 1959-b). “Yalnızlar Rıhtımı Dolayısıyla Attila İlhan'ın Cevabı”. Vatan: 4. 
Yıldırım, T. (2016). 1950’ler sonu Türk sinema eleştirisinin “türsüzleștirme” uygulaması: Üç Arkadaș (1958) ve Yalmı乏lar Rəhtımı (1959) melodramlarının eleştirel alımlamaları ve estetik çözümlemeleri. Journal of Human Sciences, 13(2), 3181-3203. doi:10.14687/ihs.v13i2.3945

Journot, M.-T. (2005). "Des courants et des genres : du Réalisme poétique à l'esthétique publicitaire”. Le Cinéma français face aux genres. Raphaëlle Moine (Ed.). Paris: AFRHC: 47-55.

Kakınç, T. D. (25 Ağustos 1957). “Köy Filmleri Dramı”. Pazar Postasi: 9

Kayalı, K. (1994). Yönetmenler Cerçevesinde Türk Sineması Üz̧erine Bir Yorum Denemesi. Ankara: Ayyıldız.

Kolker, R. (2009). Film, Biçim ve Kültür. Çev. Fırat Ertınaz, vd. Ankara: De Ki.

Lobato, R. \& Ryan, M. D. (2012). "Rethinking genre studies through distribution analysis: issues in international horror movie circuits". New Review of Film and Television Studies 9(2): 1-16. doi: 10.1080/17400309.2011.556944 View Article: DOI: http://dx.doi.org/10.1080/17400309.2011.556944

Moine, R. (2008). Les genres du cinéma. Paris: Armand Colin.

Okan, T. ( 27 Nisan 1957). "Sazlı Damin Kahpesi”. Milliyet. 2.

_ (19 Aralık 1958). "Üç Arkadaş”. Milliyet. 2.

_ (30 Ekim 1959). "Yalnızlar Rihtımı". Milliyet. 2.

Onaran, Â. Ş. (1990). Lütfi Ö. Akad. İstanbul: AFA.

— (1994). Türk Sineması I. Ankara: Kitle.

Özgüç, A. (2005). Türlerle Türk Sineması Dönemler - Modalar - Tiplemeler. İstanbul: Dünya Kitapları.

Özön, N. (1959 [1995]). “Sinemamız ve Melodram”. Dost 17: 139-146.

_ (1961 [1995]). "Üçüncü Boyut”. Türk Dili 115: 91-94.

— (1985). Sinema Uygulayım Sanatı Taribi. İstanbul: Hil.

_ (1990). 100 Soruda Sinema Sanatı. İstanbul: Gerçek.

_ (1995). Karagözden Sinemaya Türk Sineması ve Sorunlar Cilt 1. Ankara: Kitle.

_ (2013). Türk Sineması Taribi: 1896-1960. İstanbul: Doruk.

Pinel, V. (2009). Genres et mowvements au cinéma. Paris: Larousse.

Refiğ, H. (1956). "İntikam Alevi”. Akis 133: 24.

_ (1957). "Mevsimin yerli Filmleri”. Akis 160: 32.

— (1959-a). "Üç Arkadaş”. Akis 236: 27.

— (1959-b). "Hazır İyimserken...". Akis 236: 28.

_ (8 Kasım 1959-c). "Rıhtımlarda Sinema Şiiri”. Pazar Postast: 11-12.

_ (1 Ekim 1960). "Bilinmeyen Muharrem Gürses". Vatan: 4-5.

Scognamillo, G. (1998). Türk Sinema Taribi. İstanbul: Kabalc1.

Sezer, B. (22 Mayıs 1959). “Türk Film Festivali, Yarışmaya Katılan Filmler”. Akesam: 4.

Tirard, L. (2016). “Jean-Luc Godard ile Master Class”. Çev. Oğuz Tecimen. Notos 56: 56-61.

Tokatlı, E. (24 Mayıs 1959-a). "Türk Film Festivali, Birinciliğe Aday: Üç Arkadaş”. Akşam: 3.

_ (28 Haziran 1959-b). “Üç Arkadaş İçin”. Paz̧ar Postası: 10.

Tuğrul, S. (7 Şubat 1954). "Hıçkırık”. Dünya: 4.

Ün M. \& Ün U. (2009). Memdub Ün Filmlerini Anlatiyor. Kabalc1: İstanbul.

Yıldırım, T. (2015-a). “Türk Sinema Tarihyazımı ve Türler: Yeşilçam'ın Oluşum Döneminde Başat Türlerin Eleştirel Söylem Üzerinden Tanımlanması (1948-1959)". Doğu Batı 72: 26-65.

_ (2015-b). “Türk Sinema Tarihyazımı ve Türler: Yeşilçam’ın Standart Türlerine Giriş Tarihi Filmler - Komediler - Polisiyeler (1948-1959)”. Doğu Batı 73: 208-244.

_ (2015-c). “Türk Sinema Tarihyazımı ve Türler: Yeşilçam’ın Standart Türlerine Giriş Melodramlar - Köy Filmleri (1948-1959)”. Doğu Batı 74: 29-65. 
Yıldırım, T. (2016). 1950’ler sonu Türk sinema eleştirisinin “türsüzleştirme” uygulaması: Ü̧̧ Arkadaşs (1958) ve Yalmı̨lar Rıbtımı (1959) melodramlarının eleştirel alımlamaları ve estetik çözümlemeleri. Journal of Human Sciences, 13(2), 3181-3203. doi:10.14687/ihs.v13i2.3945

\section{EKLER:}

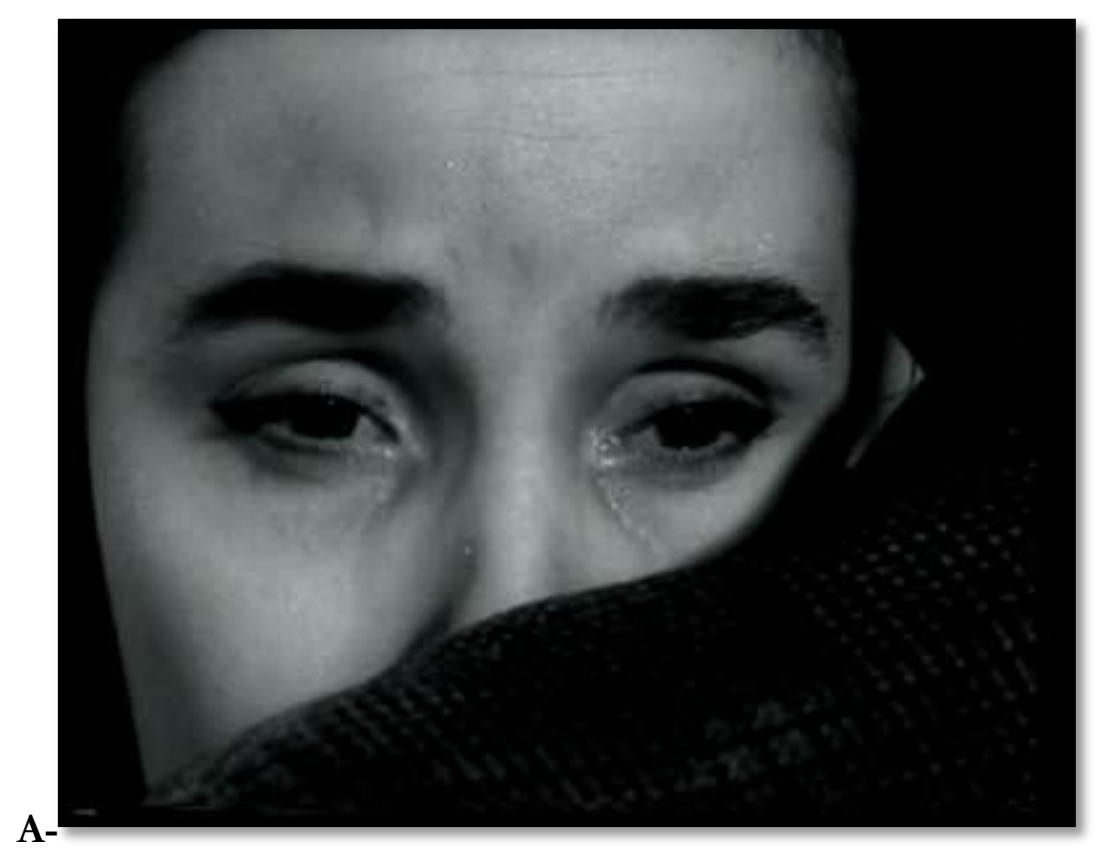

Plan-A: Donuk bakışlı ve görmeyen gözleriyle Gül melodram evrenine uygun biçimde masum ve kurban kadın rolündedir. Kendi başına büyük şehirde var olma şansı olmayan bu zayıf ve kurtarılmayı bekleyen terk edilmiş kadını ayaktakımından üç melek kalpli erkek kurtaracaktır. Yakın çekimde gösterilen, görmeyen gözlerinden akan ve kadere sitem eden gözyaşları sayesinde seyirci Ü̧̧ Arkadaş anlatısının bu mutsuz karakteriyle özdeşleşir. Hüzün ve acıma duygularından kaynaklanan patetik etki kaçınılmazdır.

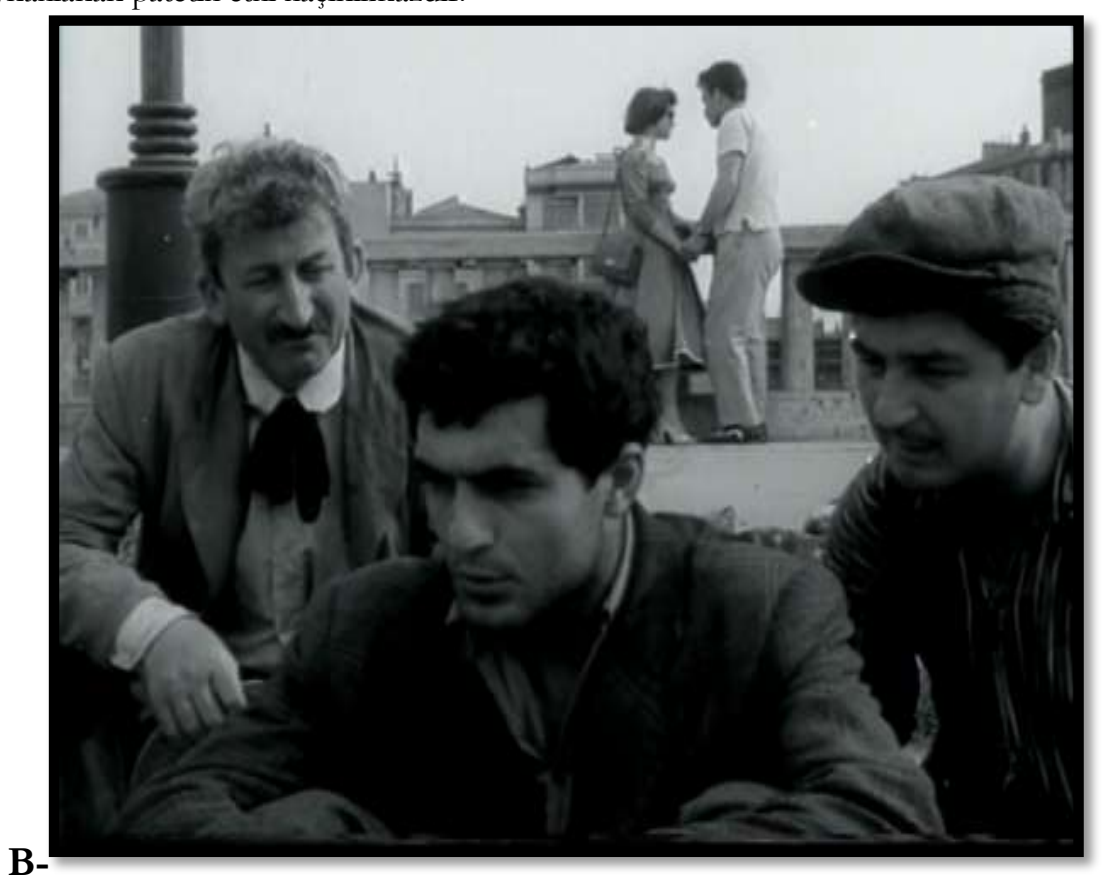

Plan-B: Üç Arkadaş’ın en ilginç biçimsel özelliği alan derinliği kullanımıdır. Ön plandaki niyetçi Murat'1, orta plana yerleştirilmiş yakın arkadaşları olan seyyar fotoğrafçı Artin ve sokakta ayakkabı boyayan Mıstık teselli etmeye çalışmaktadır. Bu kafadarlar ters üçgen bir kompozisyon biçiminde yerleştirilir. Arka plandaki kavuşan âşsk çiftin mutluluğu ile Gül'e delicesine âşık fakir Murat'ın üzüntüsü tezat oluşturmaktadır. O genç çiftin dipte olmasının sebebi Murat ile Gül'ün kavuşamadığını vurgulamaktır. Yönetmen Ün, böylece ön plan ile arka plan arasında duygusal bir diyalektik yaratır. 
Yıldırım, T. (2016). 1950’ler sonu Türk sinema eleştirisinin “türsüzleştirme” uygulaması: Ü̧̧ Arkadaşs (1958) ve Yalmı̨lar Rəbtımı (1959) melodramlarının eleştirel alımlamaları ve estetik çözümlemeleri. Journal of Human Sciences, 13(2), 3181-3203. doi:10.14687/jhs.v13i2.3945

C-

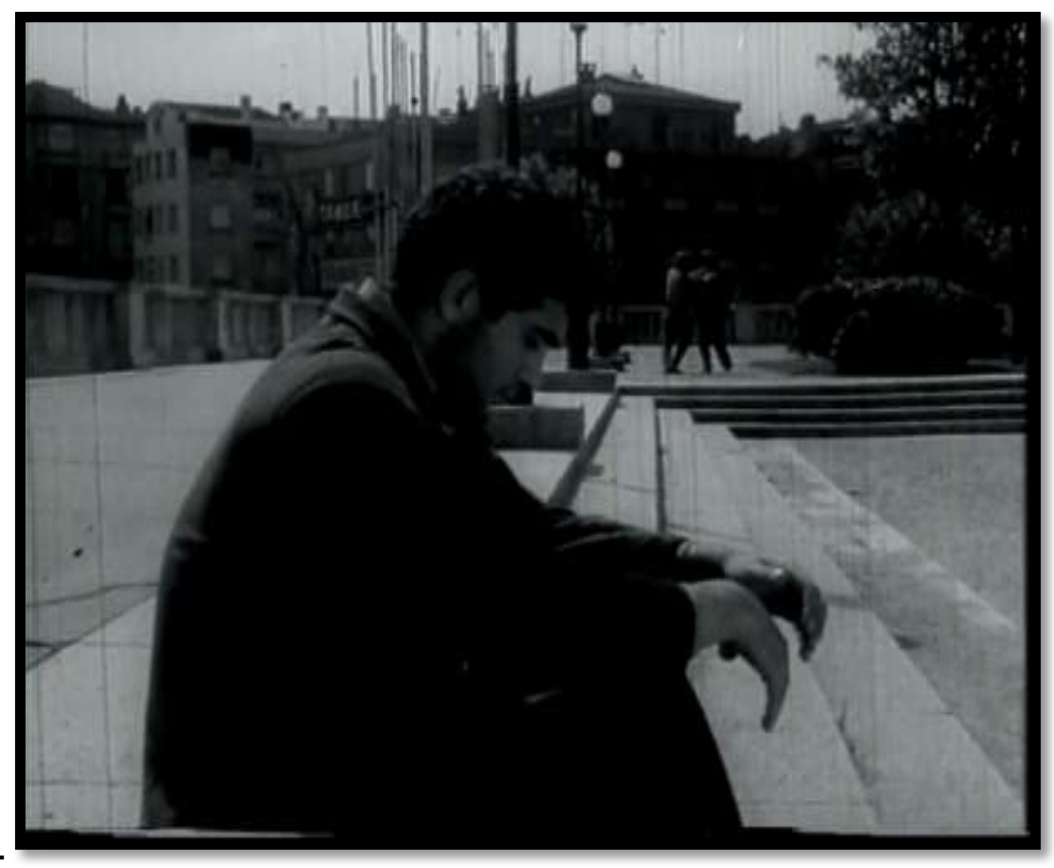

Plan-C: Sol ön planda profilden görüntülenen Murat, aşkı Gül'ün nerede olduğunu sonunda bulmuştur. Başının öne eğik olması duygusal sıkıntıda olduğunu gösterir. Zengin şarkıcıya dönüşen ve sosyal statüsü değişen sevdiği kadını görmeye gitmeye çekinmektedir. Bundan habersiz iki kafadar dostu Artin Usta ile Mistık ise sağ arka planda mutluluktan dans etmektedir. Önden arkaya her figür tamamen nettir. Ün, ana kişilerin duygusal farklılıklarını üçüncü boyut kullanımı ile başarılı şekilde görselleştirmektedir. Murat'ın başının hizasındaki elektrik lambalarının dikeyliği ile iki arkadaşının tarafinda konumlanan merdivenlerin yataylı̆̆ da bu içsel tezatı çizgisel biçimde görselleştirir. Oysa aynı yönetmen sınıfsal farklılıkları keskin biçimde göstermede çok çekingendir. $\ddot{U} c$ Arkadaş’ın küçük adamın ahlaki üstünlügüne dayalı basit konusunun ötesinde, gerçekçi estetikle ilişkilendirilen bu modern sinematografik formel öğe (alan derinliği) tercihi eleştirmenlerin ilgisini çekmiş olmalıdır. Ün’ün sinematografisi, dış mekânda (yani doğal dekorda) yapılan uzun kaydırmalı çekimleri, siyah-beyaz kontrastına dayalı bir tonlamayı; mizanseni ise ışık-gölge oyunlarını kapsar.

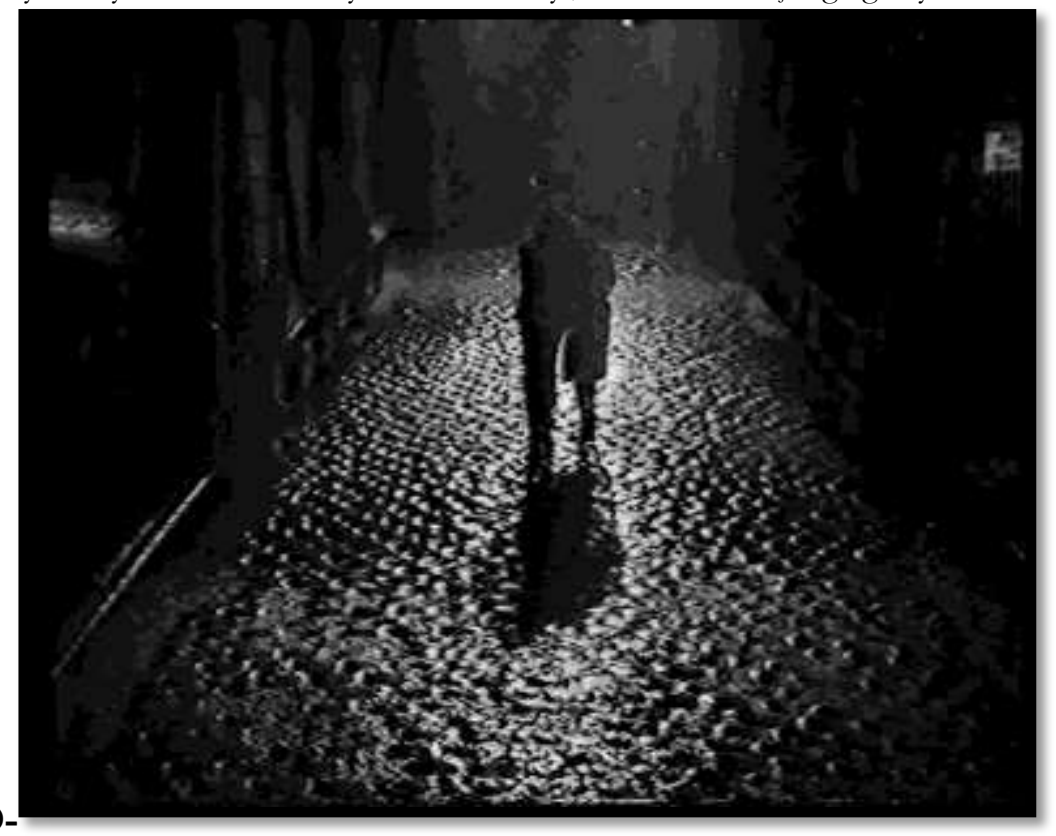

Plan-D: Kaptan ile kontesin birleşen siluetleri, ters ışıkla yıkanmış yağmurlu bir mekânda kamera dikey çevrinme hareketi yaparken yavaşça uzaklaşmaktadır. Birbirlerine kavuşan bu yalnızlara ne olacağı konusu muallâkta bırakılır çünkü Yalmıllar Rıbtıminın açık sonu kesin bir cevap vermez. Akad, mekânı dramatize eden ve kasvetini arttıran ters 1şık, gölge ve siluet kullanımına polisiye filmi Kanun Namına'dan beri alışıktır. Bu kontrastı yüksek görsel estetik tercih, 1920’lerin ekspresyonist sinemasına katkıda bulunmuş Alman görüntü yönetmenleri ile çalışan Marcel Carné'nin flu görüntülerle dolu gri tonlu filmlerinden ayrılan ve 1940’ların sinemasının görsel geleneğinin izinden giden bir stildir. 
Yıldırım, T. (2016). 1950’ler sonu Türk sinema eleştirisinin “türsüzleștirme” uygulaması: Ụ̈ Arkadaș (1958) ve Yalmı乏lar Rəhtımı (1959) melodramlarının eleştirel alımlamaları ve estetik çözümlemeleri. Journal of Human Sciences, 13(2), 3181-3203. doi:10.14687/jhs.v13i2.3945

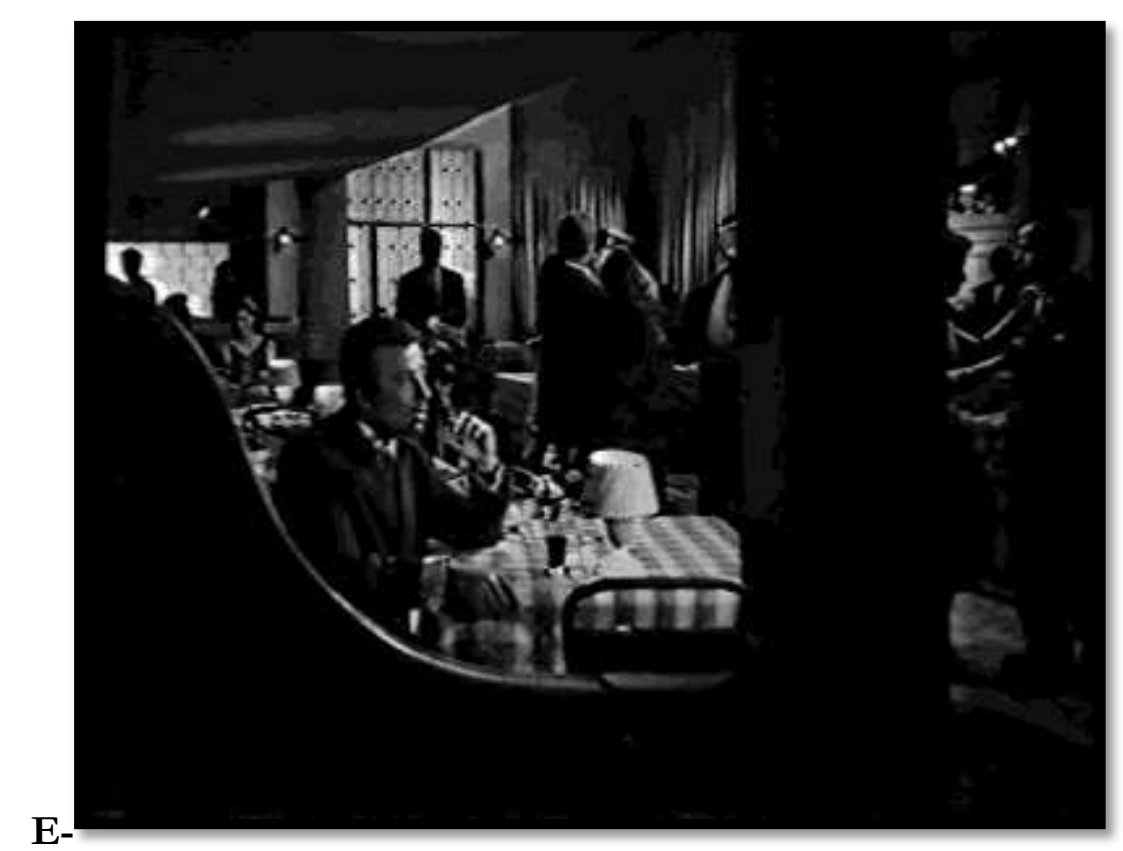

Plan-E: Çerçeve içinde çerçeve ile kuşatılan kaptan, dış alanda şarkı söyleyen kontesi dikkatle dinlemekte ve seyretmektedir. Üççeyreklik açı ve geniş alan derinliği kullanımı net görülen figürleri, özel aydınlatma ile siluet veya yarısiluet halinde bırakılan figürlerle çevreler. Masa üzerine yerleştirilmiş abajurlu lambalar ve fondaki duvara monte edilmiş lambalar üç boyutlu mekânı dramatize eden 1şık kaynaklarını açıkça gösterir. Yalnı̨̧lar Rıbtımi’ndaki geniş açı kullanımı yönetmenin derinlemesine mizansen arzusunun bir sonucudur. Akad'ın kısa odaklı geniş açılı mercek ve alan derinlikli dekupaj kullanımları, Orson Welles’in ve Jean Renoir'ın 1940’larda yaptıkları gerçekçi filmlerin izinden gitmektedir. Akad, Kanun Namına'da denediği bu görsel stilin Yalnı̨lar Rıbtımı'nda çok daha gelişmiş biçimini sunar.

\section{Extended English Abstract}

This study named 'The practice of 'de-genrification' of the Turkish film criticism in the late 1950's: The critical receptions and aesthetic analysis of melodramas like Three friends (1958) and Port of the Lonely (1959)" has proved that the critical discourse of subject period ignored the identity of genres for mentioned films but it especially emphasized the identity of film director. Thereby, it was proven that the film criticism which is assumed to have an important function in recognition of genres of film acted out of the scope of "genrification model" created by Rick Altman and it exposes the films examined to the "practice of de-genrification" because of some aesthetic and ideological reasons.

The main purpose of this article was proving that film criticism which is accepted to have the role of genrification in genre studies that occupies a very important place in cinematology executes the function of de-genrification because of various arbitrary reasons (negligence of genres which is known as the trademark of popular cinema, partisanship of absolute realism, passion for the art cinema, an excessive auteur eulogy, ideological perspectives etc.). Carrying out the case study in order to bring the empirical legitimacy to the concept of practice of de-genrification was essential. The examples of melodrama and representatives which are absolutely despised and accepted as an enemy genre for cinema when it comes to the Turkish film criticism of 1950s could be used as an irreplaceable subset for the solution to this problematic. Here the thing which should have been done was finding film(s) that were slandered at this period and the fact that it belongs to mentioned genre will be proven with aesthetic analyzes but at the same time whose identity of genres was ignored by critics' environment. 
Yıldırım, T. (2016). 1950’ler sonu Türk sinema eleştirisinin “türsüzleștirme” uygulaması: Ụ̈ Arkadaș (1958) ve Yalnı̨lar Rəhtımı (1959) melodramlarının eleştirel alımlamaları ve estetik çözümlemeleri. Journal of Human Sciences, 13(2), 3181-3203. doi:10.14687/ihs.v13i2.3945

As demonstrated also by this study, Turkish film criticism that was predominantly under the thumb of leftist ideology at the end of 1950s has described the dominant melodrama genre of mainstream Yeşilsam cinema as outside the cinema and located it against the realistic cinema. This critical discourse described the melodramatic one and realist one as two inconsistent aesthetic characters that can never come side by side. Thereby, Three friends made by Memduh Ün and Port of the Lonely made by Lütfi Ömer Akad which attracted the notice of film criticism because of their high artistic qualities have been evaluated from the perspective of a pure auteurist approach. The director identities of artists were recognized immediately but, the identity of genres of works were ignored. It means that, common critical discourse denied and ignored the melodramatic properties of these films. The rejectionist and ambiguous attitude can be seen obviously.

The comparative double reading of Three friends and Port of the Lonely expressed that critical discourse of 1950s has certainly ignored these hybrid melodramas consist of complex aesthetic features. However, as indicated by the comparative film analyses done in article, it is impossible to evaluate the Three friends that is under the influence of romantic comedy movie of Charlie Chaplin named City Lights (1931) out of the melodramatic-realistic aesthetic, because comic one and pathetic one intertwine in this hybrid movie. In the same way, Port of the Lonely which was affected from the French poetic realist cinema movement of 1930s about creating a visual atmosphere combines gangster film features with melodrama conventions through a hybrid aesthetic attitude. In fact, there was shown that both hybrid melodramas took inspiration from some realist cinema aesthetic forms (depth of field, long fixed or tracking shots, the use of simultaneous mise en scène through cast placed to foreground and background, long takes etc.) popularized by some famous directors as French Jean Renoir (1894-1979) and American Orson Welles (1915-1985) in Western cinematography.

This critical discourse which never trusts the genre of melodrama was maintained in traditional Turkish cinema historiography almost as is and aesthetic analysis of some genres of film belong to Turkish cinema was delayed accordingly. The actions to be taken from now on are exceeding the limits of director based narrow perspective while writing the aesthetic history of Turkish cinema and accepting reality of "film genre" which affects the styles of the directors as well as the contents of the movies.

\section{Analytical filmography:}

Three friends:

DIRECTOR: Memduh Ün; SCENARIO: Aydın Arakon, Metin Erksan, Muammer Çubukçu, Memduh Ün, Ertem Göreç, Atıf Yılmaz Batıbeki; CAST: Muhterem Nur, Fikret Hakan, Salih Tozan, Semih Sezerli; PRODUCTION COMPANY: Emin Film; PRODUCER: Talat Emin; PRODUCTION YEAR: 1958; FIRST RUN: December 1958; FORMAT: $35 \mathrm{~mm}$; COLOR: black-and-white.

\section{Port of the Lonely:}

DIRECTOR: Lütfi Ömer Akad; SCENARIO: Attila İlhan (Ali Kaptanoğlu mahlasiyla), Lütfi Ömer Akad; CAST: Çolpan İlhan, Sadri Alışı, Turgut Özatay, Melahat İçli, Osman Alyanak, Sadettin Erbil; PRODUCTION COMPANY: İpek Film (FITAŞ); PRODUCER: İhsan İpekçi; PRODUCTION YEAR: 1959; FIRST RUN: October 1959; FORMAT: 35 mm; COLOR: black-and-white. 